\title{
Chemical composition, sources, and processes of urban aerosols during summertime in northwest China: insights from high-resolution aerosol mass spectrometry
}

\author{
J. Xu ${ }^{1}$, Q. Zhang ${ }^{2}$, M. Chen ${ }^{3}$, X. Ge ${ }^{2}$, J. Ren ${ }^{1}$, and D. Qin ${ }^{1}$ \\ ${ }^{1}$ State Key Laboratory of Cryospheric Sciences, Cold and Arid Regions Environmental and \\ Engineering Research Institute, CAS, Lanzhou 730000, China \\ ${ }^{2}$ Department of Environmental Toxicology, University of California, Davis, CA 95616, USA \\ ${ }^{3}$ College of Atmospheric Science, Lanzhou University, Lanzhou 730000, China
}

Correspondence to: J. Xu (jzxu@1zb.ac.cn)

Received: 15 May 2014 - Published in Atmos. Chem. Phys. Discuss.: 19 June 2014

Revised: 25 September 2014 - Accepted: 23 October 2014 - Published: 1 December 2014

\begin{abstract}
An Aerodyne high-resolution time-of-flight aerosol mass spectrometer (HR-ToF-AMS) was deployed along with a scanning mobility particle sizer (SMPS) and a multi-angle absorption photometer (MAAP) to measure the temporal variations of the mass loading, chemical composition, and size distribution of submicron particulate matter $\left(\mathrm{PM}_{1}\right)$ in Lanzhou, northwest China, during 11 July-7 August 2012. The average $\mathrm{PM}_{1}$ mass concentration including non-refractory $\mathrm{PM}_{1}\left(\mathrm{NR}-\mathrm{PM}_{1}\right)$ measured by HR-ToF-AMS and black carbon (BC) measured by MAAP during this study was $24.5 \mu \mathrm{g} \mathrm{m}^{-3}$ (ranging from 0.86 to $105 \mu \mathrm{g} \mathrm{m}^{-3}$ ), with a mean composition consisting of $47 \%$ organics, $16 \%$ sulfate, $12 \% \mathrm{BC}, 11 \%$ ammonium, $10 \%$ nitrate, and $4 \%$ chloride. Organic aerosol (OA) on average consisted of $70 \%$ carbon, $21 \%$ oxygen, $8 \%$ hydrogen, and $1 \%$ nitrogen, with the average oxygen-to-carbon ratio $(\mathrm{O} / \mathrm{C})$ of 0.33 and organic mass-to-carbon ratio (OM/OC) of 1.58. Positive matrix factorization (PMF) of the high-resolution organic mass spectra identified four distinct factors which represent, respectively, two primary OA (POA) emission sources (traffic and food cooking) and two secondary OA (SOA) types - a fresher, semi-volatile oxygenated OA (SV-OOA) and a more aged, low-volatility oxygenated OA (LV-OOA). Trafficrelated hydrocarbon-like $\mathrm{OA}(\mathrm{HOA})$ and $\mathrm{BC}$ displayed distinct diurnal patterns, both with peak at 07:00-11:00 (BJT: UTC +8), corresponding to the morning rush hours, while cooking-emission related OA (COA) peaked during three meal periods. The diurnal profiles of sulfate and LV-OOA
\end{abstract}

displayed a broad peak between $\sim$ 07:00 and 15:00, while those of nitrate, ammonium, and SV-OOA showed a narrower peak between $\sim 08: 00-13: 00$. The later morning and early afternoon maximum in the diurnal profiles of secondary aerosol species was likely caused by downward mixing of pollutants aloft, which were likely produced in the residual layer decoupled from the boundary layer during nighttime. The mass spectrum of SV-OOA was similar to that of coal combustion aerosol and likely influenced by coal combustion activities in Lanzhou during summer. The sources of BC were estimated by a linear decomposition algorithm that uses the time series of the NR-PM 1 components. Our results indicate that a main source of $\mathrm{BC}$ was local traffic $(47 \%)$ and that transport of regionally processed air masses also contributed significantly to BC observed in Lanzhou. Finally, the concentration and source of polycyclic aromatic hydrocarbons (PAHs) were evaluated.

\section{Introduction}

Air pollution has become a serious issue in China due to rapid urbanization and industrialization in recent years (Chan and Yao, 2008, and references therein). Lanzhou - the capital of Gansu province in northwest China - is located in a valley basin with the Yellow River flowing across the city, along the northeast of the Qinghai-Xizang (Tibet) Plateau. With a population of $\sim 3.6$ million (including its surround- 
ings), Lanzhou is one of the most polluted cities in China during winter and spring (Qu et al., 2010; Yang et al., 2011). The monthly mean mass concentration of the total suspended particles (TSP) during winter and spring was found to reach as high as $300 \mu \mathrm{g} \mathrm{m}^{-3}$ (Chu et al., 2008). Generally, poor air quality in Lanzhou is attributed to several important factors: (1) the valley's trough-shaped topography, which often results in an inversion during winter and spring and traps pollutants at the ground level (Hu and Zhang, 1999); (2) coal consumption for industrial and residential heating during wintertime, which can lead to emissions of large amounts of particulate and gaseous pollutants (Zhang et al., 2000); (3) large amounts of dust particles, especially during spring, due to the frequent dust storm events originated from the Hexi Corridor region in northwestern China (Wang et al., 2005); and (4) rapidly increasing vehicle usage, which was estimated to contribute an increasingly large fraction of the air pollutants in recent years (Zhou, 1997).

Various mitigation strategies have been implemented to improve air quality in Lanzhou (http://xb.gansudaily.com. cn/system/2012/02/07/012358883.shtml). For example, one measure is to reduce local industrial and domestic emissions (Xia et al., 2008) via the implementation of central heating during winter; another is called the Moving Mountain Project and plans to remove the $1689 \mathrm{~m}$ high Daqingshan Mountain to the east of the city (http://www.newschinamag.com/ magazine/removing-mountains) in order to improve ventilation. As a result, air quality during the past 10 years in Lanzhou has been improving (Qu et al., 2010; Wang et al., 2012), with the number of days with particulate matter (PM) loading violating the National Ambient Air Quality Standards of China significantly decreased during winter and spring (Yu et al., 2011). In addition, a recent field study conducted at a suburban site in the Xigu district showed that summertime photochemical pollution at this location has been reduced as well, though still rather serious (Zhang et al., 2009). However, after 2005, due to the rapid increase of on-road vehicles, automobile exhaust-related pollution in Lanzhou has become increasingly significant, similar to the situations in other cities in China (Lu et al., 2011).

Previous studies in Lanzhou mostly focused on particle mass loading ( $\mathrm{PM}_{10}$ and TSP) and optical properties (Zhang and Friedlander, 2000). The chemical characteristics of atmospheric particles were rarely discussed. Since 2013, the air quality standards in China have placed greater focus on regulating atmospheric fine particles $\left(\mathrm{PM}_{2.5}\right)$. In comparison to coarse particles, fine particles are generally more chemically complex, more susceptible to regional and long-range transport in the atmosphere, and more detrimental to human health. Understanding the composition, sources, and processes of $\mathrm{PM}_{2.5}$ is particularly important for developing strategies to reduce the environmental impacts of air pollution. In addition, since most air quality studies in Lanzhou were conducted in winter and spring, very little is known about aerosol chemistry in summer.
In recent years, understanding of the physicochemical properties and sources of airborne fine particles has been greatly improved via use of Aerodyne aerosol mass spectrometers (AMS) (Canagaratna et al., 2007; Zhang et al., 2007a; Jimenez et al., 2009). AMS detects non-refractory (NR) submicron particles $\left(\mathrm{PM}_{1}\right)$ quantitatively including organics, sulfate, nitrate, ammonium, and chloride (Jayne et al., 2000). AMS can also provide information on the size distributions of species via a combination of aerodynamic lens, chopper, and particle time-of-flight (PToF) detection. NR-PM ${ }_{1}$ components can be quantitatively determined by analyzing the ensemble mass spectra acquired with the AMS (Allan et al., 2004). Using a highresolution time-of-flight AMS (HR-ToF-AMS, mass resolution of $\sim 5000-6000 \mathrm{~m} / \Delta \mathrm{m}$ ) (DeCarlo et al., 2006), one can also obtain ion-speciated mass spectra which allow the determination of the atomic ratios among oxygen $(\mathrm{O})$, carbon $(\mathrm{C})$, hydrogen $(\mathrm{H})$, nitrogen $(\mathrm{N})$, and sulfur $(\mathrm{S})$ in organic aerosol (OA) (Aiken et al., 2008). The $\mathrm{O} / \mathrm{C}$ ratio (i.e., oxidation degree) can be used to indicate the evolution (aging) of organics (Ng et al., 2010) and aerosol hygroscopicity (Jimenez et al., 2009). In addition, using advanced data analysis techniques, the ensemble mass spectral matrix can be analyzed to obtain valuable information on the mass loading, processing history, and sources of the particulate organics (Zhang et al., 2011a).

Since 2006, over a dozen field studies in China employed Aerodyne AMS and aerosol chemical speciation monitor (ACSM) (Ng et al., 2011b) for in situ chemical characterization of aerosols. Except for the present study, all studies were conducted in eastern China (Fig. 1), in the three major urban agglomerations, i.e., Beijing-Tianjin-Tangshan Area, Yangtze River Delta, and Pearl River Delta. The specific locations include Beijing (Takegawa et al., 2009; Huang et al., 2010; Sun et al., 2010, 2012a, 2013; Zhang et al., 2011b), Changdao in Shandong province (Hu et al., 2013), Shanghai (Huang et al., 2012), Jiaxing in Zhejiang province (Huang et al., 2013), Kaiping (Huang et al., 2011), Shenzhen (He et al., 2011) and Back-Garden (Xiao et al., 2011) in Guangdong province, and Hongkong (Lee et al., 2013). The campaignaverage $\mathrm{PM}_{1}$ mass concentration generally ranged from 15 to $67 \mu \mathrm{g} \mathrm{m}^{-3}$, in which organics were usually a dominant component (28-52\% of $\left.\mathrm{PM}_{1}\right)$ and the sources of the organics included traffic emission, cooking related activities, coal combustion, and secondary OA (SOA) formation. Figure 1 shows a summary of the average $\mathrm{PM}_{1}$ concentration and composition observed during each study (data are available in Table S1 in the Supplement). These highly time-resolved chemical measurements have yielded valuable insights into the characteristics, sources, and processes of PM pollution in several urban and urban downwind areas in eastern China.

Although the western, inland area of China is facing severe air pollution similar to that in eastern China, very little is known about the chemistry and properties of aerosol pollution in this region. To address this, we conducted a measurement campaign in summer 2012 to characterize the tem- 


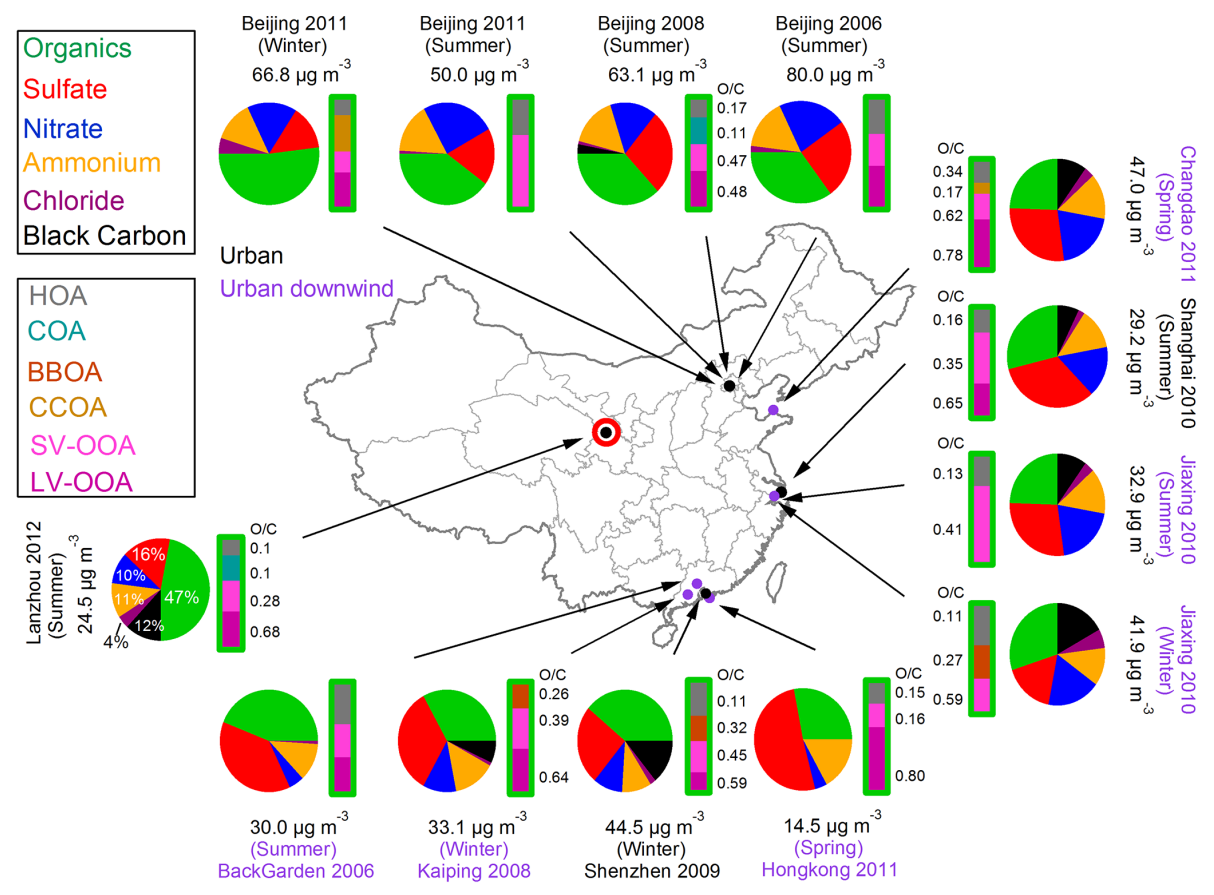

Figure 1. Summary of aerosol mass spectrometer (AMS) measurements in China. In each site, total mass concentration, mass fractions (pie chart), and OA components based on positive matrix factorization (PMF) analysis (column) are shown. The O/C ratios for each OA component are also shown for several studies that used HR-ToF-AMS.

poral variations of the composition and size distribution of $\mathrm{PM}_{1}$ in Lanzhou, mainly with an Aerodyne HR-ToF-AMS. This study also represents the first real-time measurement of aerosol chemistry in western China (Fig. 1). Here, we report an overview of the main results from this study, such as mass loading, size distribution, and temporal and diurnal variations of $\mathrm{PM}_{1}$. Based on these data, we discuss the sources and chemical processes of fine particles in this urban area.

\section{Experimental methods}

\subsection{Aerosol sampling and instrumentation}

This study was conducted from 11 July to 7 August 2012 in Lanzhou. A suite of instruments were deployed, including an HR-ToF-AMS (Aerodyne, Inc., Billerica, MA, USA) for size-resolved chemical composition of NR-PM 1 , a scanning mobility particle sizer (SMPS, model 3936, TSI, Shoreview, MN, USA) for number concentration and size distribution of particles ranging from 13 to $650 \mathrm{~nm}$ in mobility diameter $\left(D_{\mathrm{m}}\right)$, a multi-angle absorption photometer (MAAP, model 5012, Thermo Electron Cooperation) for black carbon (BC) concentration, and a cloud and aerosol microlidar (model CE 370-2, CIMEL \& CNRS) for the vertical distribution of atmospheric aerosols. These instruments were operated at two nearby sites $(\sim 300 \mathrm{~m}$ apart) divided by an east-west arterial road in the Chengguan district of Lanzhou (Fig. 2c). The HR-ToF-AMS and SMPS were lo- cated at a seven-story academic building in the Cold and Arid Regions Environmental and Engineering Research Institute (CAREERI site), whereas the MAAP and micro-lidar were deployed in a two-story academic building on the campus of Lanzhou University (LZU site). The Chengguan district is located in eastern Lanzhou, a densely populated area occupied by government, commerce, culture, and residence structures with relatively few industrial facilities. Supporting meteorological and air quality data were obtained from the government monitor stations located in the same district. The date and time used in this paper are given as Beijing Time (BJT: UTC +8 ). Note that the local time of Lanzhou is $1 \mathrm{~h}$ later than BJT.

\subsubsection{Sampling sites}

The CAREERI sampling site $\left(36.05^{\circ} \mathrm{N}, 103.86^{\circ} \mathrm{W}\right)$ was located inside an air conditioned room on the top floor (7th) of an academic building. The room temperature was kept at $\sim 25^{\circ} \mathrm{C}$. CAREERI is inside a semi-enclosed area with two busy roads lying $\sim 50 \mathrm{~m}$ to the south and the east of the campus, respectively. The measurement site, however, is not directly exposed to car exhaust emissions since it is behind a building of similar height which is $\sim 20 \mathrm{~m}$ from the roads. The sampling inlet, constructed using 0.375 -inch copper tube and a $\mathrm{PM}_{2.5}$ cyclone (URG Corp., Chapel Hill, NC), protruded above the building roof by about $1.5 \mathrm{~m}, \sim 20 \mathrm{~m}$ above the ground level. The sampling inlet was shared by the HR- 

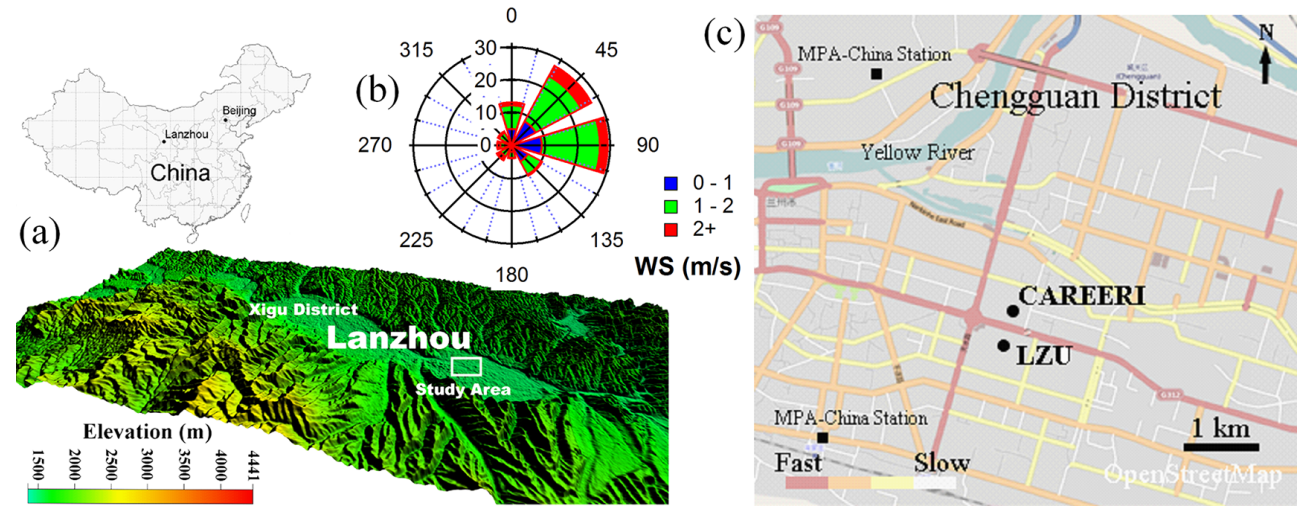

Figure 2. (a) Location map of Lanzhou and digital elevation model (DEM) map of the geomorphic features of Lanzhou Basin and its adjacent areas. (b) Wind rose plot colored by wind speed during the period of the 2012 Lanzhou study. (c) Two sampling sites of this study (CAREERI and LZU) and two air quality stations (MPA-China, affiliated to the Ministry of Environmental Protection of the People's Republic of China). Elevation data are provided by International Scientific Data Service Platform, Computer Network Information Center, Chinese Academy of Sciences (http://datamirror.csdb.cn).

ToF-AMS and the SMPS and an extra pump was used to maintain the required flow rate $\left(10 \mathrm{~L} \mathrm{~min}^{-1}\right)$ for the $\mathrm{PM}_{2.5}$ size cut. The residence time of aerosol in the sampling line was about $1.5 \mathrm{~s}$. A diffusion dryer was used to remove moisture prior to sampling by the HR-ToF-AMS and SMPS.

The LZU site was located inside a two-story building on the campus of Lanzhou University, $\sim 300 \mathrm{~m}$ south of the CAREERI site. The MAAP was housed in a room kept at $\sim 25^{\circ} \mathrm{C}$ and ambient air was aspirated from the rooftop of the building using a 0.5 -inch anti-static tube $(1.5 \mathrm{~m})$ with a $\mathrm{PM}_{2.5}$ impactor, at a flow rate of $16.7 \mathrm{~L} \mathrm{~min}^{-1}$. The data acquired with $670 \mathrm{~nm}$ light were saved at $1 \mathrm{~min}$ intervals.

\subsubsection{HR-ToF-AMS operation}

Instrumentation details of the HR-ToF-AMS are described elsewhere (DeCarlo et al., 2006). Briefly, particles are focused into a narrow particle beam via an aerodynamic lens and analyzed via a combination of thermal vaporization $\left(\sim 600^{\circ}\right)$ under high vacuum $\left(\sim 10^{-8}\right.$ torr $)$, electron impact ionization $(70 \mathrm{eV})$ of vaporized molecules, and mass spectrometry determination. The particle size can be obtained using a mechanical chopper to allow the particle velocities to be determined. During this study, the AMS data were collected continuously and averaged over $2.5 \mathrm{~min}$ intervals. The mass spectrometer toggled between "V"-mode (high sensitivity for quantification of individual species, detection limits $\sim 10 \mathrm{ng} \mathrm{m}^{-3}$ ) and "W"-mode (high chemical resolution for organic analysis, $\sim 6000 \mathrm{~m} / \Delta \mathrm{m}$ in this study) every $2.5 \mathrm{~min}$. Under V-mode, the instrument also switched between the mass spectrum mode and the PToF mode every $15 \mathrm{~s}$, spending 6 and $9 \mathrm{~s}$ on each. Size distribution data are reported in terms of mass-weighted vacuum aerodynamic diameter ( $\mathrm{d} M / \mathrm{d} \log D_{\text {va }}$ ). No PToF data were collected in $\mathrm{W}$-mode due to low signal-to-noise $(S / N)$ ratio.
Calibrations of particle size and ionization efficiency (IE) of the HR-ToF-AMS were performed using standard polystyrene latex (PSL) spheres (Duke Scientific Corp., Palo Alto, CA) and mono-dispersed ammonium nitrate particles, respectively, at the beginning and in the middle of the field study according to the standard protocol detailed in Jayne et al. (2000). Particulate-free ambient air was sampled at the end of the study (21:05-22:00 on 6 August and 10:40-11:45 on 7 August) to determine the detection limits (DLs) of individual species and also for adjusting the fragmentation table. The DLs were calculated as 3 times the standard deviations $(3 \sigma)$ of the measured values during this period (Zhang et al., 2005b). The 2.5-min DLs for organics, sulfate, nitrate, ammonium, and chloride were determined at 0.066, 0.008, $0.0054,0.008,0.013 \mu \mathrm{g} \mathrm{m}^{-3}$, which are comparable to the values reported in previous studies (Table S2).

\subsection{HR-ToF-AMS data analysis}

\subsubsection{General analysis}

The HR-ToF-AMS data were processed using the standard ToF-AMS analysis toolkit SQUIRREL $(\mathrm{v} 1.51 \mathrm{H})$ and PIKA $(\mathrm{v} 1.10 \mathrm{H})$ modules available online at http://cires.colorado.edu/jimenez-group/ ToFAMSResources/ToFSoftware/index.html, written in Igor Pro (Wavemetrics, Portland, OR, USA). A few modifications were made to the standard fragmentation table of Allan et al. (2004) for better signal apportionments. Based on data acquired during the filtered air period, adjustments were made to refine the gaseous contributions to the measured $\mathrm{CO}_{2}^{+}$signal and the ${ }^{16} \mathrm{O}^{+}$to ${ }^{14} \mathrm{~N}^{+}$ratio for air signal. In addition, the signals of $\mathrm{H}_{2} \mathrm{O}^{+}$and $\mathrm{CO}^{+}$ for organics were scaled to that of $\mathrm{CO}_{2}^{+}$according to the scaling factors proposed by Aiken et al. (2008) for ambient measurements: $\mathrm{CO}^{+}=\mathrm{CO}_{2}^{+}$and $\mathrm{H}_{2} \mathrm{O}^{+}=0.225 \times \mathrm{CO}_{2}^{+}$, 
while the fragmentation pattern of $\mathrm{H}_{2} \mathrm{O}^{+}$was determined based on the values observed for the background water signal: $\mathrm{HO}^{+}=0.23 \times \mathrm{H}_{2} \mathrm{O}^{+}$and $\mathrm{O}^{+}=0.04 \times \mathrm{H}_{2} \mathrm{O}^{+}$. Note that since ambient $\mathrm{CO}_{2}$ concentration varies as a function of time, the subtraction of a constant $\mathrm{CO}_{2}$ signal $(400 \mathrm{ppm}$ based on filtered-air measurement in this study) may introduce uncertainties in the quantification of the organic- $\mathrm{CO}_{2}^{+}$ signal, which is determined as the difference between total $\mathrm{CO}_{2}^{+}$and air- $\mathrm{CO}_{2}^{+}$, and the $\mathrm{O} / \mathrm{C}$ ratio of $\mathrm{OA}$ (Collier and Zhang, 2013). However, this artifact was expected to be very small due to the high OA concentration and thus relatively small contribution of air- $\mathrm{CO}_{2}^{+}$signal to the total $\mathrm{CO}_{2}^{+}$ signal during this study. For example, we estimate that a variation of $\mathrm{CO}_{2}$ concentration between 350 and $500 \mathrm{ppm}$ may introduce $-3-5 \%$ error in organic- $\mathrm{CO}_{2}^{+}$quantification. In addition, a collection efficiency (CE) of 0.5 was used in this study.

\subsubsection{PMF analysis}

PMF analysis using the PMF2.exe algorithm (v4.2) in robust mode (Paatero and Tapper, 1994) was performed to determine distinct OA factors representing specific sources/processes. The analysis was conducted and evaluated using the PMF Evaluation Toolkit (PET) v2.03 (Ulbrich et al., 2009) downloaded from: http://cires.colorado.edu/jimenez-group/wiki/index.php/

PMF-AMS_Analysis_Guide. The ion-speciated spectral matrix and the corresponding error matrix were obtained from analyzing the $\mathrm{W}$-mode data via PIKA fitting. Prior to PMF analysis, data pretreatments were performed following the procedures outlined in Table 1 of Zhang et al. (2011a). We only included ions with $m / z$ up to 120 amu given that larger ions tend to have low $S / N$ ratios and require higher mass resolution to resolve due to the large number of possible isobaric ions. Isotopic ions were excluded because their signals are not directly measured but scaled to their parent ions. Similarly, the four ions of $\mathrm{O}^{+}, \mathrm{HO}^{+}, \mathrm{H}_{2} \mathrm{O}^{+}$, and $\mathrm{CO}^{+}$, which were scaled to the $\mathrm{CO}_{2}^{+}$signal, were downweighted by increasing their errors by a factor of 3 , to ease the excess weight given to $\mathrm{CO}_{2}^{+}$in PMF analysis (Ulbrich et al., 2009). The "bad" and "weak" ions with $0.2<S / N<0.2$ and $S / N<2$, respectively, were removed and further downweighted by increasing their errors by a factor of 2 , as well as for some runs with huge mass loading spikes.

The PMF solutions were investigated for 1 to 8 factors and for the rotational parameter (fPeak) varying from -1 to 1 (step $=0.1$ ), and evaluated following the procedures detailed in Table 1 of Zhang et al. (2011a). A summary of the key diagnostic plots is presented in Fig. S5. The 4-factor solution with $\mathrm{fPeak}=0$ was chosen in this work, as it is able to reconstruct the total OA mass and temporal profiles very well, and can be very well justified; for example, the mass spectra of the four individual factors agree the best with the reference spectra from specific sources or other ambient AMS measurements (see Sect. 3.6 for details). For comparisons, the 3factor solution and 5-factor solution are shown in Fig. S3 and Fig. S4, respectively. Obviously, the 3-factor solution does not separate correctly hydrocarbon-like OA (HOA) and semivolatile OA (SV-OOA), while the 5-factor solution shows the splitting of a SV-OOA factor from the 4-factor solution.

\subsubsection{Determination of the size distributions of the $\mathrm{OA}$ factors and estimation of $\mathrm{BC}$ sources}

The size distributions of individual OA factors were determined via a multivariate linear regression technique (Ge et al., 2012a; Sun et al., 2012b). This algorithm assumes that each OA mass spectrum is the linear superposition of the mass spectra of individual OA factors, whose mass profiles are constant across the whole size range, consistent with the assumption for 2-D and 3-D PMF analysis of the AMS data (Ulbrich et al., 2009; Ulbrich et al., 2012), as shown in superposition:

$\mathrm{ms}_{i}=\sum_{p=1}^{n}\left(\mathrm{~ms}_{p} \times c_{p, i}\right)$,

where $\mathrm{ms}_{i}$ refers to the measured mass spectrum (in unit mass resolution, $\mathrm{UMR}$ ) of total $\mathrm{OA}$ for size bin $i, \mathrm{~ms}_{p}$ is the UMR mass spectrum of factor $p$ from PMF analysis, $c_{p, i}$ refers to the corresponding fitting coefficient which is the mass of factor $p$ distributed in size bin $i$, and $n$ is the total number of factors used in the fitting. In this study, the size-resolved OA mass spectra (up to $120 \mathrm{amu}$ ) in the size range of 40-1200 nm in vacuum aerodynamic diameter $\left(D_{\mathrm{va}}\right)$ is averaged into 20 size bins equally spaced on log scale (Fig. S9). Given the similarity between the mass spectra of the semi-volatile and low volatility oxygenated OA factors (see Sect. 3.6.3), we merged them in a mass-weighted way to generate the mass spectrum of a combined OOA factor (OOA). The mass spectra of OOA, cooking-emission related OA (COA), and HOA were then used to determine the average size distributions of these three OA types. The fitting results are presented in Fig. S10. The size distribution of each PMF factor is finally normalized to its mass concentration.

In order to examine the sources and atmospheric processing of BC in Lanzhou, we applied a linear decomposition algorithm (Zhang et al., 2005a) to apportion the measured BC mass concentration; the time series of $\mathrm{BC}$ was linearly decomposed using the time series of the four OA factors (PMF results), nitrate, and sulfate, as follows:

$t_{\mathrm{BC}}=\sum_{p=1}^{6} t_{p} \times c_{p}$,

where $t_{\mathrm{BC}}$ denotes the time series of $\mathrm{BC}$ mass concentration, $t_{p}$ denotes the time series of inorganic species or OA factors $p$, and $c_{p}$ denotes the corresponding fitting parameter. 
Table 1. Correlation coefficient $\left(r^{2}\right)$ between time series of OA factors and other aerosol species.

\begin{tabular}{lcccccc}
\hline$r^{2}$ & COA & HOA & POA $^{*}$ & SV-OOA & LV-OOA & SOA $^{*}$ \\
\hline BC & 0.03 & 0.66 & 0.23 & 0.48 & 0.01 & 0.24 \\
Sulfate & 0.01 & 0.04 & 0.03 & 0.19 & 0.41 & 0.44 \\
Nitrate & 0.04 & 0.16 & 0.11 & 0.50 & 0.15 & 0.48 \\
Ammonium & 0.02 & 0.14 & 0.07 & 0.32 & 0.20 & 0.40 \\
Chloride & 0.01 & 0.20 & 0.07 & 0.17 & 0.00 & 0.08 \\
Sulfate + nitrate & 0.03 & 0.13 & 0.09 & 0.46 & 0.32 & 0.59 \\
Sulfate + nitrate + chloride & 0.03 & 0.17 & 0.10 & 0.45 & 0.21 & 0.49 \\
\hline
\end{tabular}

$* \mathrm{POA}=\mathrm{COA}+\mathrm{HOA}, \mathrm{SOA}=\mathrm{SV}-\mathrm{OOA}+\mathrm{LV}-\mathrm{OOA}$

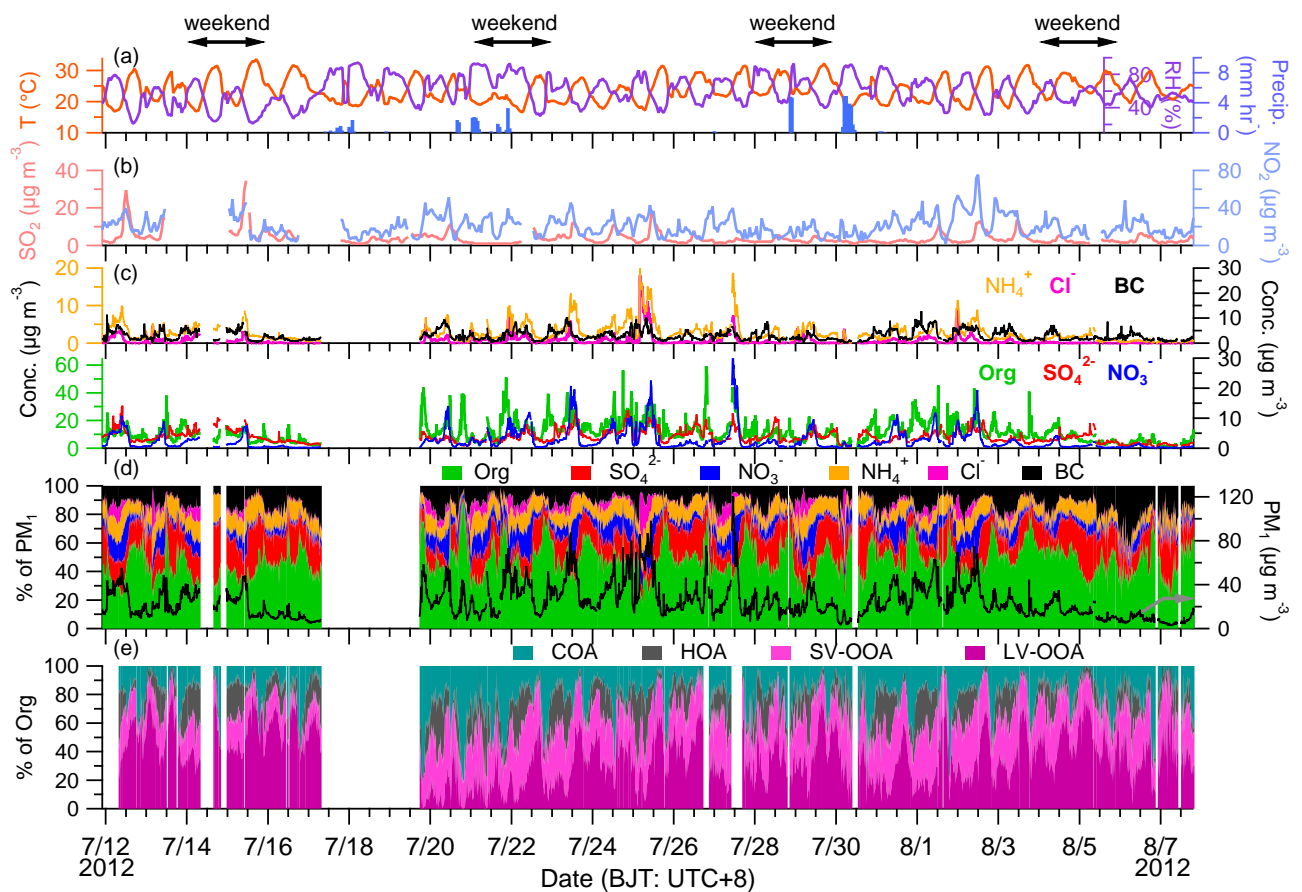

Figure 3. Time series of (a) air temperature ( $T$ ), relative humidity (RH) and precipitation (Precip.), (b) average mass concentration ( $\mu \mathrm{g} \mathrm{m}^{-3}$ ) of $\mathrm{SO}_{2}$ and $\mathrm{NO}_{2}$ from two MPA-China stations, (c) mass concentration of $\mathrm{PM}_{1}$ species, (d) mass concentrations of total $\mathrm{PM}_{1}$ (right $y$ axis) and the fractional contribution of each species to the total $\mathrm{PM}_{1}$, and (e) the contributions of PMF factors to total organics.

\section{Results and discussion}

\subsection{Overview of field study}

Figure 3 presents an overview of the temporal changes of the meteorological conditions, the concentrations of gas pollutants, NR-PM 1 species, and $\mathrm{BC}$ measured during this study. The meteorological conditions were relatively stable and the weather during this study period was overall sunny with mild air temperature, moderate RH, and light winds. For example, the average daytime (09:00-20:00) vs. nighttime (21:00-08:00) of air temperature was 26 vs. $21^{\circ} \mathrm{C}$ with an average $( \pm 1 \sigma)$ of $23.8( \pm 3.8)^{\circ} \mathrm{C}$ for the entire study period, and the average daytime vs. nighttime RH was $51 \%$ vs. $68 \%$ with an average value of $60( \pm 17) \%$. Three mod- erate rain events $\left(<10 \mathrm{~mm} \mathrm{hr}^{-1}\right)$ occurred during this study and two occurred around the weekend (Fig. 3a). Wind speed (WS) was generally low, varying from 0 to $5 \mathrm{~m} \mathrm{~s}^{-1}$ with an average value of $1.2( \pm 0.6) \mathrm{m} \mathrm{s}^{-1}$ and the surface wind directions (WDs) were predominantly east and northeast (Fig. 2b), which were associated with summer monsoons at East Asia.

The concentrations of all $\mathrm{PM}_{1}$ species varied dynamically during this study, with the hourly average of total $\mathrm{PM}_{1}$ mass (defined as the sum of AMS-measured NR$\mathrm{PM}_{1}$ and $\mathrm{BC}$ ) varying from 0.86 to $105 \mu \mathrm{g} \mathrm{m} \mathrm{m}^{-3}$ (average $\pm 1 \sigma=24.5 \pm 15.2 \mu \mathrm{g} \mathrm{m}^{-3}$ ) for the entire study (Fig. 3c). The $24 \mathrm{~h}$ average $\mathrm{PM}_{1}$ concentration ranged from 5.7 to $40 \mu \mathrm{g}$ $\mathrm{m}^{-3}$. The average $\mathrm{PM}_{1}$ mass concentration in this study $\left(24.5 \mu \mathrm{g} \mathrm{m}^{-3}\right)$ is significantly lower than the $\mathrm{PM}_{2.5}$ loading $\left(66 \pm 15 \mu \mathrm{g} \mathrm{m}^{-3}\right)$ observed during 18 June to 17 July 2006 

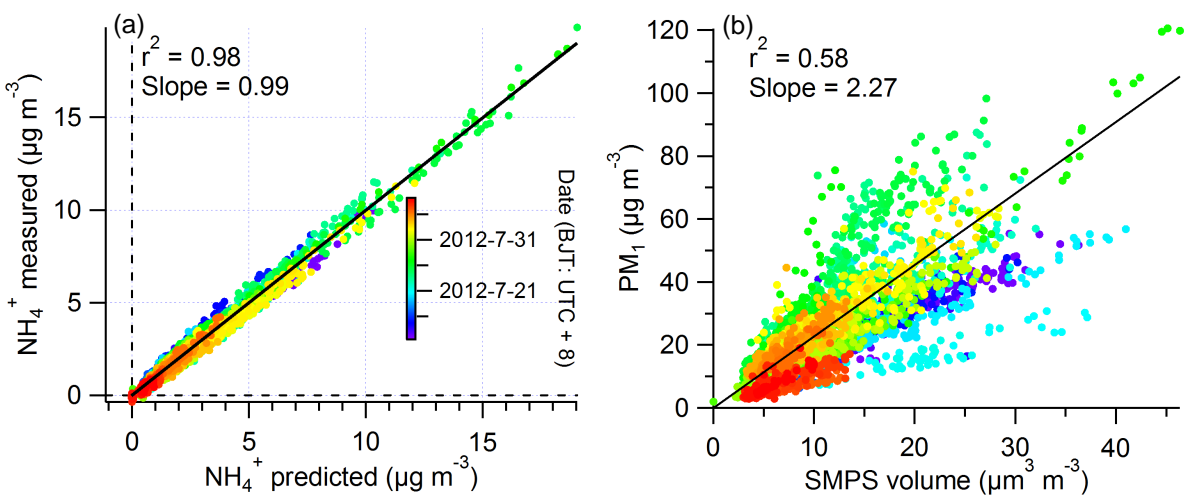

Figure 4. Scatterplot of (a) measured vs. predicted $\mathrm{NH}_{4}^{+}$and (b) $\mathrm{PM}_{1}$ mass concentrations $\left(\mathrm{NR}-\mathrm{PM}_{1}+\mathrm{BC}\right)$ vs. particle volumes from the SMPS by assuming spherical particles. The predicted $\mathrm{NH}_{4}^{+}$was calculated by assuming full neutralization of the anions - sulfate, nitrate and chloride, i.e., $\mathrm{NH}_{4}^{+}$predicted $=18 \times\left(2 \times \mathrm{SO}_{4}^{2-} / 96+\mathrm{NO}_{3}^{-} / 62+\mathrm{Cl}^{-} / 35.5\right)($ Zhang et al., 2007b).

in Lanzhou (Pathak et al., 2011a). However, dust, which accounted for $\sim 35 \%$ of the $\mathrm{PM}_{2.5}$ mass during the 2006 study, was not detected by AMS. In addition, the smaller size cut of the AMS ( $\mathrm{PM}_{1}$ vs. $\mathrm{PM}_{2.5}$ ) might also be the reason for the lower $\mathrm{PM}_{1}$ mass loading. The $\mathrm{PM}_{2.5}$ mass concentration monitored by the Ministry of Environmental Protection of the People's Republic of China (MPA-China), which is only available from 2013 in Lanzhou, was on average $48 \mu \mathrm{g}$ $\mathrm{m}^{-3}$ for July 2013 (http://www.ghjczxz.cn/Web/NewsShow. asp?id=1927). Assuming that the atmospheric conditions and pollutant emission rates in Lanzhou were similar between 2012 and 2013, we estimate that $\mathrm{PM}_{1}$ accounted for $51 \%$ of $\mathrm{PM}_{2.5}$, similar to observations in Beijing (56-64\%) (Zhang et al., 2011b; Sun et al., 2012a). Compared to the $\mathrm{PM}_{1}$ mass loading (15-67 $\mu \mathrm{g} \mathrm{m}^{-3}$ ) from AMS observations made in other Chinese cities (Fig. 1, Table S1) during different years, the average value of this study lies in the lower end of the range, indicating relatively less severe air pollution in Lanzhou during summer 2012.

The mass fractions of all species in $\mathrm{PM}_{1}$ varied dynamically (Fig. 3d). Organics dominated $\mathrm{PM}_{1}$ mass with an average contribution of $47 \%$, followed by sulfate (16\%), BC $(12 \%)$, ammonium (11\%), nitrate (10\%), and chloride (4\%) (Fig. 1). Compared to AMS observations made in other Chinese cities (Fig. 1, Table S1), the mass fraction of organics in $\mathrm{PM}_{1}$ was significantly higher in Lanzhou (47\% vs. $\sim 30 \%$ at other locations). Sulfate was on average more abundant than nitrate in Lanzhou (16\% vs. $10 \%)$, similar to observations in eastern China during summer. However, nitrate tends to be a more important $\mathrm{PM}_{1}$ component than sulfate during cooler seasons - e.g., Beijing (nitrate $=16 \%$ vs. sulfate $=14 \%)($ Sun et al., 2013) and Changdao (28\% vs. $19 \%)$ (Hu et al., 2013) - likely due to lower sulfate production rates and lower temperature that favors particulate nitrate formation. Moreover, the contributions of $\mathrm{BC}$ and chloride were also higher in Lanzhou $(\sim 12 \%$ and $\sim 4 \%)$ than at some other urban sites $(\sim 5 \%$ and $\sim 1 \%)$ during the summer sea- son (Fig. 1), likely due to coal combustion in this region (see Sect. 3.6.3).

NR-PM ${ }_{1}$ species appeared to be neutralized throughout this study, as indicated by an overall stoichiometric balance between the anions and the cations (Zhang et al., 2007b). For example, the slope of the linear regression between the total molar equivalents of nitrate, sulfate, and chloride and that of ammonium is 0.99 (Fig. 4a). This result also indicates that the inorganic species were mainly present in the forms of $\mathrm{NH}_{4} \mathrm{NO}_{3},\left(\mathrm{NH}_{4}\right)_{2} \mathrm{SO}_{4}$, and $\mathrm{NH}_{4} \mathrm{Cl}$ in $\mathrm{PM}_{1}$.

\subsection{Comparisons of AMS measurements with other collocated instruments}

As shown in Fig. $4 \mathrm{~b}$ and Fig. S6a, the SMPS-measured particle volume (calculated by assuming spherical particles) correlated reasonably well with $\mathrm{PM}_{1}$ mass $\left(r^{2}=0.58\right)$. The slope of the linear regression of $\mathrm{PM}_{1}$ mass $(\mathrm{CE}=0.5)$ vs. the SMPS volume is 2.27 , which is significantly higher than the average $\mathrm{PM}_{1}$ density of $1.61 \mathrm{~g} \mathrm{~cm}^{-3}$ calculated based on densities of organics (1.4), $\left(\mathrm{NH}_{4}\right)_{2} \mathrm{SO} 4$ (1.78), $\mathrm{NH}_{4} \mathrm{NO}_{3}$ (1.72), $\mathrm{NH}_{4} \mathrm{Cl}$ (1.53) (Zhang et al., 2005b) and $\mathrm{BC}\left(1.8 \mathrm{~g} \mathrm{~cm}^{-3}\right.$, Bond and Bergstrom, 2006). This relatively large discrepancy, which was observed previously (Ge et al., 2012b), was likely caused by the different responses between these two instruments in their maximum transmission sizes (e.g., the AMS has partial transmission for particles up to $\sim 1.0 \mu \mathrm{m}$ whereas the upper cut-off size of the SMPS is only $\sim 650$ $\mathrm{nm}$ ) and the variation of CE of AMS depending on the chemical composition of particles. The AMS-measured massbased NR-PM 1 size distributions also showed similar evolution patterns to the particle volume distributions measured by the SMPS (Fig. S6b and c). 


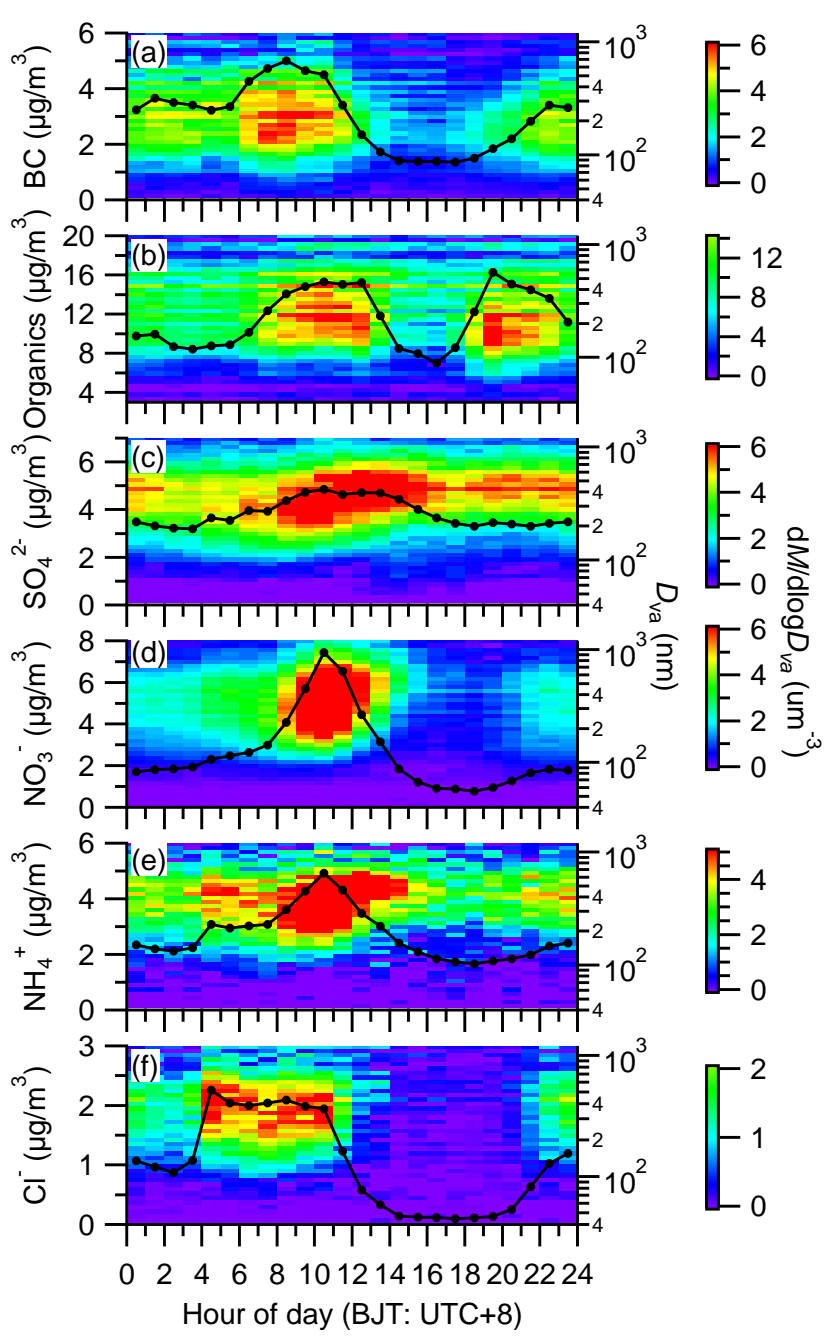

Figure 5. Diurnal profiles of the mass concentrations (black circles) and the size distributions of BC, organics, sulfate, nitrate, ammonium, and chloride.

\subsection{Diurnal variations of submicron aerosol species}

The average diurnal cycles of each $\mathrm{PM}_{1}$ species are shown in Fig. 5. BC peaked at early morning (07:00-10:00) and nighttime (Fig. 5a). Organics also displayed a morning peak during 07:00-13:00 which was broader than that of $\mathrm{BC}$ and an early evening peak between 18:00-22:00 (Fig. 5b). Further analysis revealed that the high concentration of organics during 10:00-13:00 was mainly associated with the downward mixing of a residual layer aloft when intense turbulent mixing occurred during the morning and enhanced cooking emission during lunch time. The evening OA peak appeared to be due to a combination of evening rush hours $(\sim 18: 00-20: 00$ in Lanzhou) and dinner cooking (see Sect. 3.6). The elevated $\mathrm{BC}$ concentrations during late evening and early morning (maximum at $\sim 22: 00$ ) were likely related to enhanced emissions from heavy-duty diesel trucks, which were only

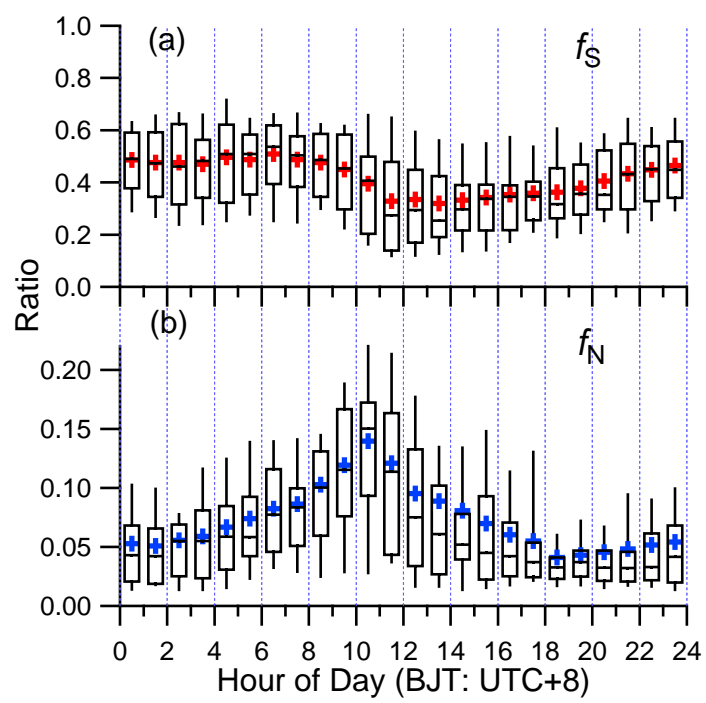

Figure 6. Diurnal variations of oxidation ratios of (a) sulfur and (b) nitrogen defined as $f_{\mathrm{S}}=n \mathrm{SO}_{4}^{2-} /\left(n \mathrm{SO}_{4}^{2-}+n \mathrm{SO}_{2}\right)$ and $f_{\mathrm{N}}=$ $n \mathrm{NO}_{3}^{2-} /\left(n \mathrm{NO}_{3}^{2-}+n \mathrm{NO}_{2}\right) . \mathrm{SO}_{2}$ and $\mathrm{NO}_{2}$ are average values from the two MPA-China stations in Lanzhou. The cross in each box is the mean value, the line is the median value, the box extends from $25 \%$ to $75 \%$ percentile, and the sticks are the 10th and 90th percentiles.

permitted to pass through the city around midnight, coupled with low boundary layer height.

Sulfate exhibited a broad peak during daytime between 09:00 and 16:00 (Fig. 5c), similar to summertime observations at some other urban sites in China (Sun et al., 2012a). Sulfate is primarily a secondary aerosol species formed from the oxidation of $\mathrm{SO}_{2}$ via both gas-phase photochemical processes and aqueous-phase processes. The sulfate peak, which coincided with the high light flux rate during daytime, suggested that photochemical processes played a leading role in sulfate formation during this study. The molar ratios of particulate sulfur to total sulfur, defined as $f_{\mathrm{S}}=n \mathrm{SO}_{4}^{2-} /\left(n \mathrm{SO}_{4}^{2-}+n \mathrm{SO}_{2}\right)$, indicate the extent of gas-toparticle conversion of sulfur. $f_{\mathrm{S}}$ increases with plume ages as a larger fraction of the $\mathrm{SO}_{2}$ is oxidized into sulfate (Brock et al., 2003). As shown in Fig. 6a, $f_{\mathrm{S}}$ started to decrease at $\sim 9: 00$ and reached a minimum at 13:00. This trend is different than the diurnal variation profiles of sulfate (Fig. 5c) and $\mathrm{SO}_{2}$ (not shown). The daytime increase of $\mathrm{SO}_{2}$, which is faster than that of sulfate, highlights a net input of $\mathrm{SO}_{2}$ to Lanzhou associated with regional transport of $\mathrm{SO}_{2}$-rich air masses during summer. Indeed, as shown in the wind roses presented in Supplement Fig. S1, wind blew predominantly from the east to northeast - a region with high anthropogenic $\mathrm{SO}_{2}$ emissions (Fig. S2) - from $\sim$ 08:00 to $\sim 12: 00 \mathrm{com}-$ bined with increased wind speed.

The diurnal variation of nitrate presented a sharp peak at $\sim$ 10:00. This pattern is somewhat different than the observations at other cities, where nitrate usually peaks during night- 
time and early morning, during which low temperature and high RH favor nitrate partitioning to the particle phase (e.g., Sun et al., 2011a). The morning peak of nitrate in Lanzhou was likely linked to the dynamics of the planetary boundary layer and nocturnal atmospheric chemistry, which can significantly alter the pollutant levels in urban areas (Nilsson et al., 2001; Pathak et al., 2011b). Generally, the boundary layer height increases during daytime due to solar activities. After sunset, a stable nocturnal boundary layer forms near the ground owing to radiative cooling and the daytime mixed-layer remains as a residual layer that is effectively separated from the surface, precluding the removal of particulate and gaseous species by deposition to the ground (Watson and Chow, 2002; Lurmann et al., 2006). Due to emissions and daytime photochemical processing, the residual layer may contain high levels of ozone, $\mathrm{NO}_{\mathrm{x}}$, volatile organic compounds (VOCs), and aerosol particles which undergo further reactions during night to form secondary pollutants. For example, $\mathrm{NO}_{\mathrm{x}}$ can react with ozone to form $\mathrm{NO}_{3}$ (nitrate radical) and $\mathrm{N}_{2} \mathrm{O}_{5}$ (dinitrogen pentoxide), which may serve as reactive intermediates and be transformed to nitric acid and other products. This nocturnal nitrate formation has been observed widely (Brown and Stutz, 2012, and reference therein). In a field study at Houston (Zaveri et al., 2010), about $40-60 \%$ of $\mathrm{NO}_{\mathrm{x}}$ in the polluted plume was found to be depleted during nighttime and converted to nitric acid, organic nitrates, and peroxy acyl nitrates via reaction of $\mathrm{NO}_{3}$ radicals with enhanced levels of olefins and aldehydes in the plume. A similar nocturnal nitrate formation was observed in some Chinese cities, such as Beijing and Shanghai (Pathak et al., 2011b). The nocturnal stable boundary layer breaks at sunrise, and as a result, aerosols and other pollutants accumulated over night in the residual layer mix downward, leading to rapid increases of pollutant concentrations in the boundary layer. The sharp increase of $f_{\mathrm{N}}\left(=\mathrm{nNO}_{3}^{2-} /\left(\mathrm{nNO}_{3}^{2-}\right.\right.$ $+\mathrm{nNO}_{2}$ ) during morning (Fig. 6b) supports this hypothesis. This mechanism has been observed at other locations with valley terrain, and matches well with our observed diurnal changes of nitrate.

The diurnal pattern of chloride showed elevated concentrations during early morning that might be attributed to the enhanced gas-particle partitioning as temperature decreased and RH increased, but remained high until 10:00, likely associated with the same boundary layer evolution as for nitrate. The diurnal variation of ammonium showed a mixed influence of nitrate and chloride, which showed a broad peak from early morning to early afternoon and a sharp peak during late morning.

\subsection{Chemically resolved size distributions of submicron aerosol species}

The average size distributions of aerosol species are shown in Fig. 7a. We derived the size distribution of $\mathrm{BC}$ based on $m / z 57$ (mainly $\mathrm{C}_{4} \mathrm{H}_{9}^{+}, 76.6 \%$ ) using the approach reported
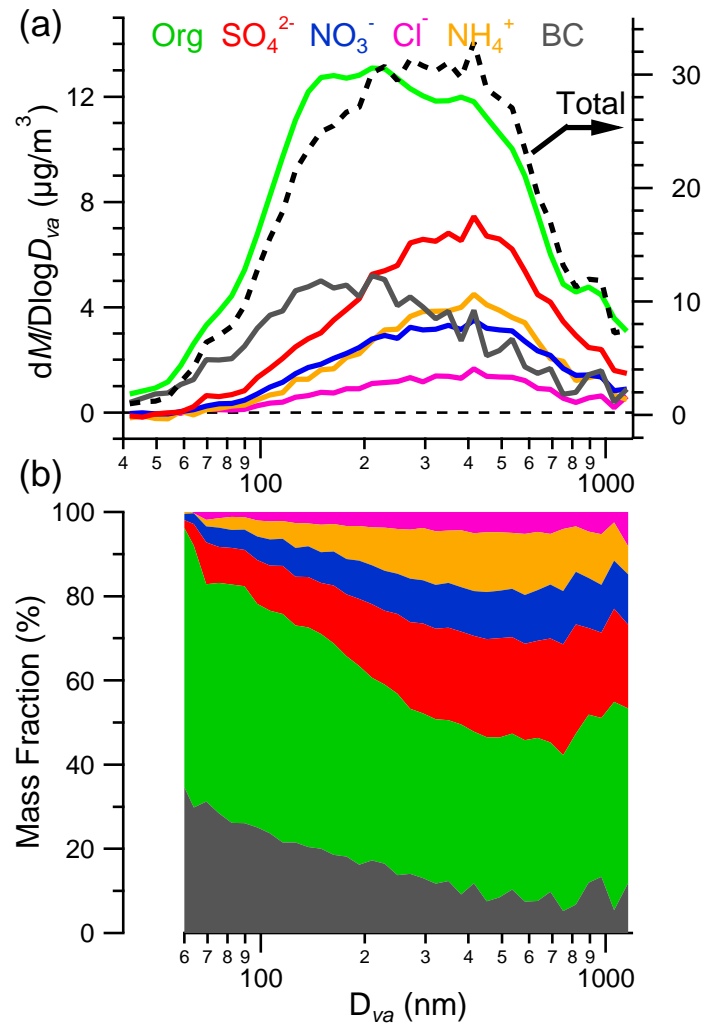

Figure 7. Average size distributions of (a) mass concentrations and (b) fractional compositions of $\mathrm{PM}_{1}$ species for the entire study. The size distribution of $\mathrm{BC}$ was estimated based on that of $m / z$ 57 (mainly $\mathrm{C}_{4} \mathrm{H}_{9}^{+}$).

in Sun et al., (2011). Note that the size distribution could be overestimated due to the contribution of $\mathrm{C}_{3} \mathrm{H}_{5} \mathrm{O}^{+}(22.3 \%)$ and other sources, such as cooking activities, to $\mathrm{C}_{4} \mathrm{H}_{9}^{+}$(Lee et al., 2014). Indeed, cooking aerosol on average contributed $33.4 \%$ of the total signal at $m / z=57$ (see Sect. 3.6.2). Overall, all secondary inorganic species showed an overlapping accumulation mode peaking at $\sim 400 \mathrm{~nm}$ in $D_{\text {va }}$ (Fig. 7a). The size distribution of BC showed a smaller mode peaking at $\sim 150 \mathrm{~nm}$, but also accounted for $\sim 10 \%$ of the particle mass in the accumulation mode $(200-1000 \mathrm{~nm})$ which is consistent with a fraction of $\mathrm{BC}$ that appeared to be associated with secondary species based on the linear decomposition results (see Sect. 3.7). In contrast to the inorganic species, the size distribution of organics showed a much broader peak ranging from $\sim 100$ to $\sim 500 \mathrm{~nm}$, suggesting the influences of different OA types. The smaller size mode is usually caused by fresh primary emissions, e.g., traffic exhaust and cooking, whereas the accumulation mode is related to secondary and aged species (e.g., Allan et al., 2003; Zhang et al., 2005b; Salcedo et al., 2006). This broader distribution of organics has been observed previously at both urban and rural locations (e.g., Sun et al., 2010, 2011a; Ge et al., 2012a; Setyan et al., 2012). In addition, for all species, the size dis- 

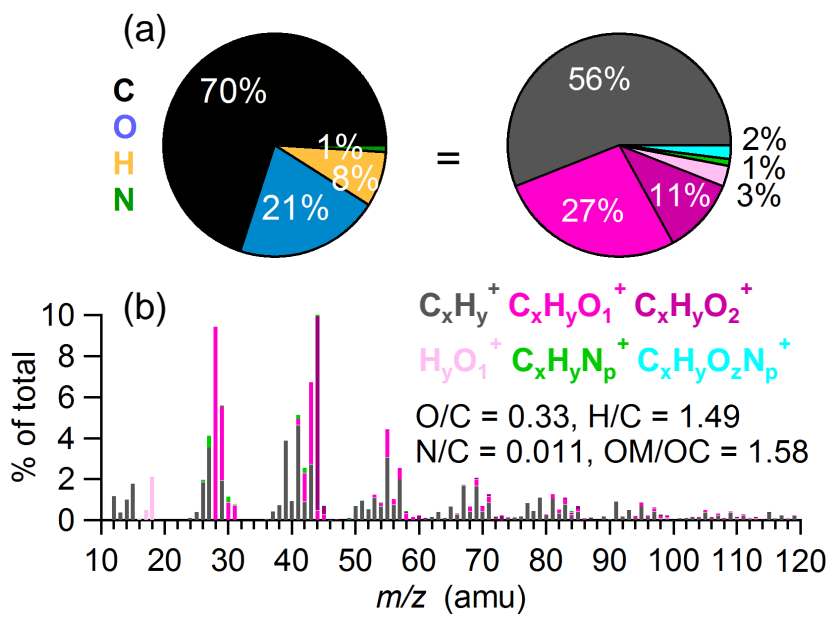

Figure 8. (a) Pie charts of OA compositions (colors show the contribution of elements, $\mathrm{C}, \mathrm{O}, \mathrm{H}$, and $\mathrm{N}$ ) and six ion categories (colors as in (b)); (b) the average high-resolution mass spectrum of OA (colors show six ion categories).

tribution showed little variation throughout the day, shifting only slightly to a bigger size $(\sim 300 \mathrm{~nm}$ to $\sim 400 \mathrm{~nm})$ when the concentrations increased (Fig. 5). The increase of mode sizes for sulfate, ammonium, and organics during the day was likely due to photochemical production of secondary species.

During this study, ultrafine particles $(<100 \mathrm{~nm})$ were dominated by BC (28\%) and organics (52\%) (Fig. 7b). The accumulation mode (300-800 nm) aerosols were mainly composed of organics and sulfate, which together account for $\sim 70 \%$ of the total mass.

\subsection{Bulk characteristics and elemental ratios of $\mathrm{OA}$}

Figure $8 \mathrm{a}$ shows the average of the mass spectrum of OA during this study. The organic mass was on average composed of $70 \%$ carbon, $21 \%$ oxygen, $8 \%$ hydrogen, and $1 \%$ nitrogen. On average, $\mathrm{C}_{\mathrm{x}} \mathrm{H}_{\mathrm{y}}^{+}$ions dominated the total OA signal $(56 \%)$, larger than all oxygenated ions combined (40\% in total), which include $\mathrm{C}_{\mathrm{x}} \mathrm{H}_{\mathrm{y}} \mathrm{O}_{1}^{+}(27 \%), \mathrm{C}_{\mathrm{x}} \mathrm{H}_{\mathrm{y}} \mathrm{O}_{2}^{+}(11 \%)$, $\mathrm{H}_{\mathrm{y}} \mathrm{O}_{1}^{+}(2 \%)$, and $\mathrm{C}_{\mathrm{x}} \mathrm{H}_{\mathrm{y}} \mathrm{N}_{\mathrm{p}} \mathrm{O}_{\mathrm{z}}^{+}(1 \%)$. Oxygen-free organic nitrogen ions $\left(\mathrm{C}_{\mathrm{x}} \mathrm{H}_{\mathrm{y}} \mathrm{N}_{\mathrm{p}}^{+}\right)$occupied the rest $\sim 3 \%$ of the total organic signals. $m / z 44$ was the base peak in the OA spectrum and mainly composed of $\mathrm{CO}_{2}^{+}(90 \%)$ and $\mathrm{C}_{2} \mathrm{H}_{4} \mathrm{O}^{+}$ ( $\sim 6 \%$ ) (Fig. 8b). $\mathrm{m} / \mathrm{z} 43 \mathrm{had}$ a significant contribution from $\mathrm{C}_{2} \mathrm{H}_{3} \mathrm{O}^{+}(41 \%)$, in addition to a dominant contribution from $\mathrm{C}_{2} \mathrm{H}_{3} \mathrm{O}^{+}(55 \%)$ and $\mathrm{CHNO}^{+}(2.7 \%)$. Previous studies have shown that the $\mathrm{CO}_{2}^{+}$fragment in the OA spectra can result from thermal decarboxylation of highly oxygenated organic acids (Takegawa et al., 2007), whereas the $\mathrm{C}_{2} \mathrm{H}_{3} \mathrm{O}^{+}$ion fragment is an indicator of less oxidized compounds. $\mathrm{m} / \mathrm{z} 57$ - an AMS spectral tracer for traffic-related emission (Zhang et al., $2005 \mathrm{a}$ ) - was dominated by $\mathrm{C}_{4} \mathrm{H}_{9}^{+}(77 \%)$, followed by $22 \%$ $\mathrm{C}_{3} \mathrm{H}_{5} \mathrm{O}^{+} . m / z$ 55, likely an important COA fragment (He et al., 2010), consisted of $69 \% \mathrm{C}_{4} \mathrm{H}_{7}^{+}$and $31 \% \mathrm{C}_{3} \mathrm{H}_{3} \mathrm{O}^{+}$.
On average, the $\mathrm{OA}$ had an $\mathrm{O} / \mathrm{C}$ of $0.33, \mathrm{H} / \mathrm{C}$ of 1.49 , and N/C of 0.011 (Fig. 8b), which yields an average organic mass-to-carbon $(\mathrm{OM} / \mathrm{OC})$ ratio of 1.58 and thus has a nominal chemical formula of $\mathrm{C}_{1} \mathrm{H}_{1.49} \mathrm{O}_{0.33} \mathrm{~N}_{0.011}$. Note that the nominal formula should not be used to infer the average molecular weight or carbon number in the OA studied here. The OM/OC of 1.58 is within the range of the AMSbased values (1.5-1.8) observed in other Chinese cities (He et al., 2011; Huang et al., 2011, 2012; Lee et al., 2013). The $\mathrm{O} / \mathrm{C}$ ratio, an indicator for the average oxidation state of $\mathrm{OA}$, in 2012 summer Lanzhou is also comparable with those in other Chinese cities (e.g., 0.30 in 2009 fall Shenzhen (He et al., 2011), 0.31 in 2010 summer Shanghai (Huang et al., 2012), 0.40 in 2011 spring Hong Kong (Lee et al., 2013), and 0.33 and 0.28 in 2010 winter and summer Jiaxing (Huang et al., 2013)), but higher than that (0.17) in 2010 winter Beijing (Liu et al., 2012) and lower than those observed at urban downwind sites (e.g., 0.47 in 2008 fall Kaiping (Huang et al., 2011) and 0.59 in 2011 spring Changdao (Hu et al., 2013)). Comparing with the $\mathrm{O} / \mathrm{C}$ values $(0.3-1)$ by the AMS on a global scale (Aiken et al., 2008; Jimenez et al., 2009), the $\mathrm{O} / \mathrm{C}$ in summer Lanzhou falls at the lower end, suggesting an overall moderately oxidized OA.

\subsection{Source apportionment of $\mathrm{OA}$}

PMF analysis of the high-resolution mass spectra of OA identified four distinct factors, each of which has a unique temporary variation and mass spectral pattern (Fig. 9). Briefly, the four factors include two OOA factors, one of which was highly oxidized and of low volatility (LV-OOA; $\mathrm{O} / \mathrm{C}=0.68$ ) and the other of which was less oxidized and appeared to be semi-volatile (SV-OOA; O $/ \mathrm{C}=0.28$ ), a $\mathrm{COA}$, and a HOA. Two OOA factors can be regarded as surrogates of SOA, with LV-OOA for more aged SOA and SVOOA for fresher SOA. The COA and HOA are primary OA (POA) based on their low $\mathrm{O} / \mathrm{C}$ ratios and good correlations with primary aerosol tracers (Fig. 9a, b). Detailed discussion on each factor, including their specific characteristics, sources, and processes, is given in the following subsections.

\subsubsection{HOA}

The mass spectrum of HOA was dominated by ions belonging to the $\mathrm{C}_{\mathrm{x}} \mathrm{H}_{\mathrm{y}}^{+}$family (79\%, Table 2), especially $\mathrm{C}_{3} \mathrm{H}_{5}^{+}(m / z=41), \mathrm{C}_{2} \mathrm{H}_{3} \mathrm{O}^{+}(m / z=43), \mathrm{C}_{4} \mathrm{H}_{7}^{+}(m / z=55)$, $\mathrm{C}_{4} \mathrm{H}_{9}^{+}(\mathrm{m} / \mathrm{z}=57), \mathrm{C}_{5} \mathrm{H}_{9}^{+}(\mathrm{m} / \mathrm{z}=69)$, and $\mathrm{C}_{5} \mathrm{H}_{11}^{+}(\mathrm{m} / \mathrm{z}=71)$ (Fig. 9f). As a result, HOA showed the highest $\mathrm{H} / \mathrm{C}$ ratio (1.84) and lowest $\mathrm{O} / \mathrm{C}$ ratio (0.10) among all factors. The HOA mass spectrum of this study (in UMR) also highly correlated with the standard HOA spectrum (Ng et al., 2011a) derived from 15 ambient HOA profiles $\left(r^{2}=0.93\right.$, Fig. S8a), and the mass spectra of organic particles emitted in diesel (Mohr et al., 2009) $\left(r^{2}=0.95\right.$, Fig. S8c) and gasoline vehicle exhausts (Canagaratna et al., 2004) $\left(r^{2}=0.88\right.$, Fig. S8b).The 

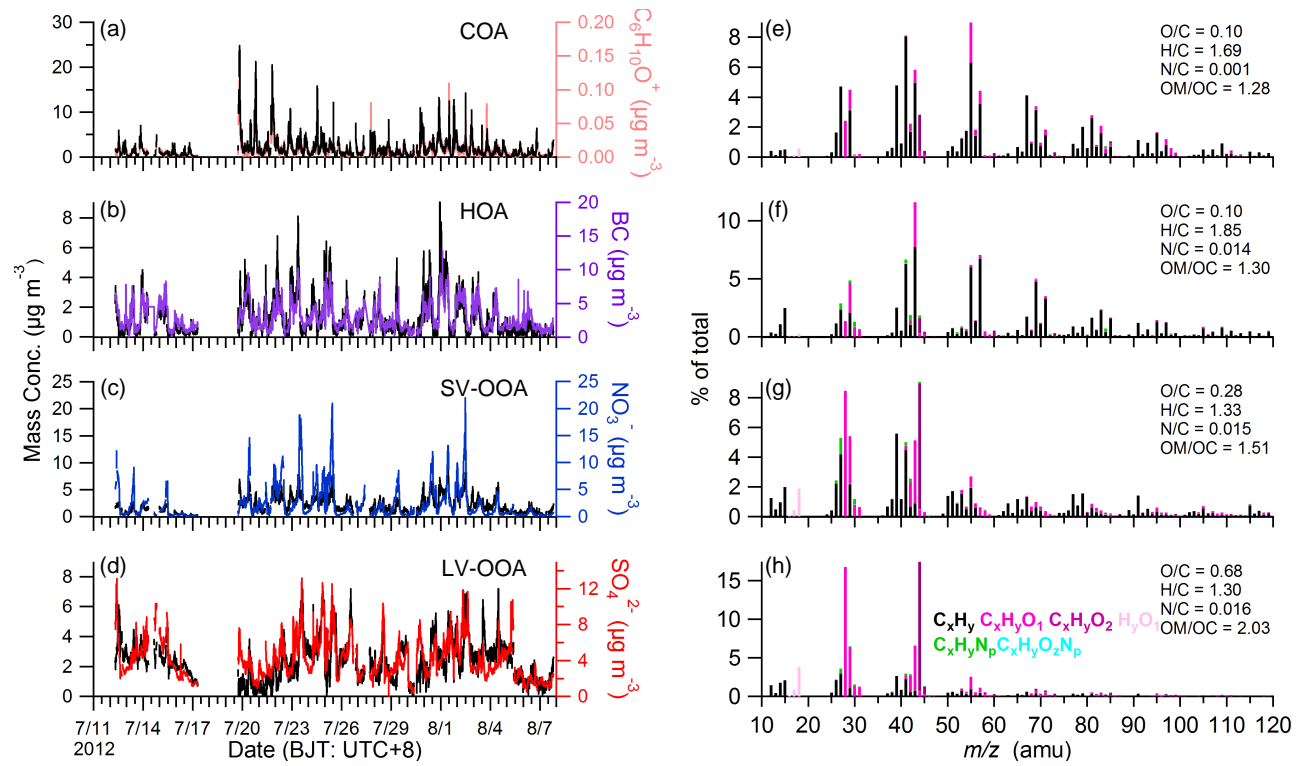

Figure 9. (a-d) Time series of PMF factor and corresponding tracer species, and (e-h) high-resolution mass spectra of four OA factors decomposed by the PMF analysis.

time series of HOA correlated well with $\mathrm{BC}\left(r^{2}=0.65\right.$, Fig. 9b) and the $\mathrm{C}_{\mathrm{x}} \mathrm{H}_{2 \mathrm{x}+1}^{+}$ions (Fig. S7b). The diurnal patterns of $\mathrm{HOA}$ and $\mathrm{BC}$ both exhibited strong morning and late evening peaks corresponding to increased traffic activities during morning rush hours and evening diesel truck traffic (Fig. 10b and Fig. 5a). These features are consistent with those of HOA observed in prior studies (Zhang et al., 2011a, and references therein). These results indicate that the HOA factor identified in this study was mainly associated with traffic emissions.

$m / z 57$ (mainly $\mathrm{C}_{4} \mathrm{H}_{9}^{+}$) can act as a tracer for $\mathrm{HOA}$ when traffic emissions are a predominant source of POA (Zhang et al., 2005a). In our study, HOA accounts for $53 \%$ of $\mathrm{m} / \mathrm{z}$. 57 (Fig. S11e), indicating that this $\mathrm{m} / z$ can reasonably represent the variation of HOA. Indeed, the size distribution of HOA is very similar to that of $\mathrm{m} / z$ 57, both peaking at $\sim 150 \mathrm{~nm}$ (Fig. S11b), and dominated the OA mass in ultrafine size range $(<70 \mathrm{~nm})$ (Fig. 11b). This peak size is similar to the HOA factors determined in Fresno (140 nm) (Ge et al., 2012a), New York City (110 nm) (Sun et al., 2012b), Boulder $(120 \mathrm{~nm})$ (Nemitz et al., 2008), and Pittsburgh $(\sim 150 \mathrm{~nm})$ (Zhang et al., 2005c), but the overall size distribution was narrower than those of the last two. We observed relatively high fractions of $\mathrm{C}_{2} \mathrm{H}_{3} \mathrm{O}^{+}$at $m / z 43$ and $\mathrm{CO}_{2}^{+}$at $m / z 44$ in HOA mass profile (Fig. 9f), indicating the presence of some oxygenated compounds in HOA, which is consistent with measurements of POA in fresh vehicle emissions (Collier et al., 2013). Another reason for relatively oxidized HOA was likely the fact that a fraction of the HOA mass was likely transported from aged OA from regional source and/or the condensation of SV-OOA on HOA as suggested by the posi-

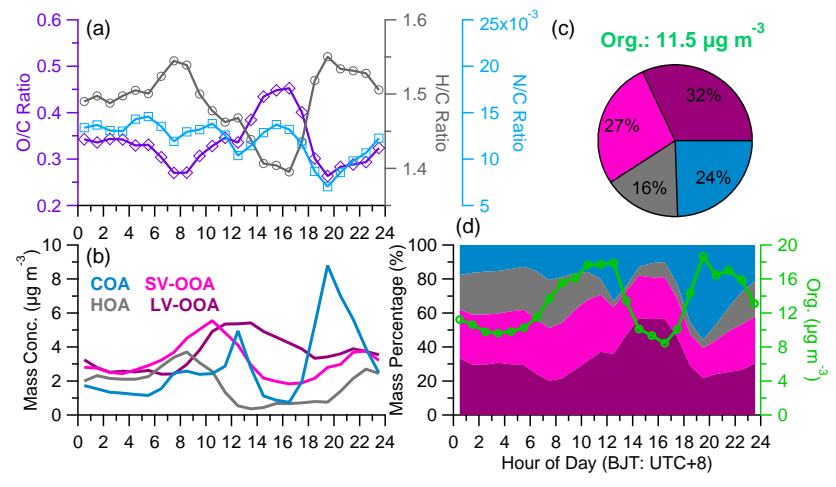

Figure 10. Diurnal patterns of (a) $\mathrm{O} / \mathrm{C}, \mathrm{H} / \mathrm{C}, \mathrm{N} / \mathrm{C}$ ratios and (b) the mass concentrations of the OA factors; (c) average mass contributions of the four OA factors to the total OA (pie chart); (d) diurnal cycles of the mass percentages of the four OA factor and the total $\mathrm{OA}$ mass concentration.

tive significant correlation $(r=0.68)$ between time series of HOA and SV-OOA (Fig. S5d).

The average mass contribution of HOA was $16 \%$ of the total OA mass (Fig. 10c). Diurnal changes of the mass fraction of HOA (Fig. 10d) presented an afternoon minimum (less than 5\% of OA mass from 12:00 to 18:00), and a morning maximum (more than $20 \%$ of OA mass from 00:00 to 08:00), which was due to the photooxidation consumption of fresh aerosol and emissions from traffic activities including late night diesel truck traffic and morning rush hours. This feature can further be supported by the diurnal variations of the elemental ratios $(\mathrm{O} / \mathrm{C}$ and $\mathrm{H} / \mathrm{C})$ of $\mathrm{OA}$ (Fig. 10a) that $\mathrm{H} / \mathrm{C}$ 


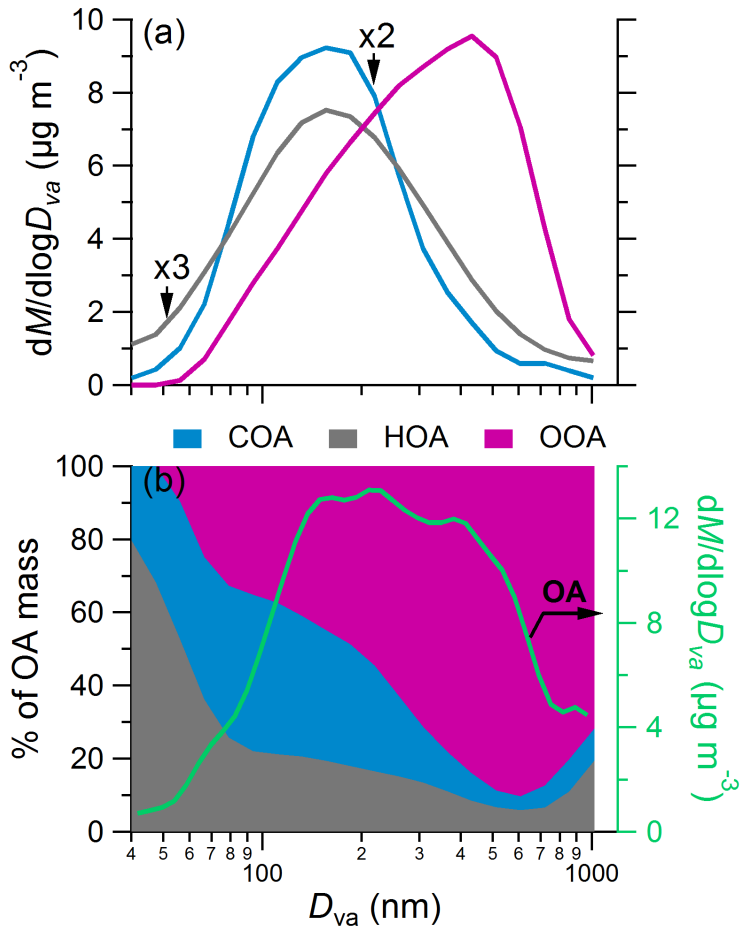

Figure 11. (a) Size distributions of individual OA factors; (b) fractional contributions of the OA components to the total OA mass at different size bins, and the mass-based total OA size distributions.

peaked at morning rush hour and evening rush hour/dinner time, while $\mathrm{O} / \mathrm{C}$ was particularly elevated in the afternoon.

\subsubsection{COA}

The mass spectrum of COA (Fig. 9e) had a similar list of most abundant ions to HOA, but the largest ones were $m / z 41$ and 55 (dominated by $\mathrm{C}_{3} \mathrm{H}_{5}^{+}$and $\mathrm{C}_{4} \mathrm{H}_{7}^{+}$, respectively), similar to the lab-generated spectral profiles of cooking aerosols (Mohr et al., 2009; He et al., 2010). The high ratio of $m / z$ $55 / 57$ (2.0) and high fraction of $m / z 55(9 \%)$ in our COA mass spectrum were consistent with the diagnostic indicator for the presence of COA proposed by Sun et al. (2011). The mass spectral profile of the COA factor determined in this study agreed well with those of the COA factors identified in previous studies at various urban areas $\left(r^{2}=0.73-0.94\right.$; Fig. S8d-i) (Allan et al., 2010; Huang et al., 2010; Sun et al., 2011a; Ge et al., 2012a; Mohr et al., 2012; Sanchez-Lorenzo et al., 2012; Crippa et al., 2013). The $\mathrm{O} / \mathrm{C}$ and $\mathrm{H} / \mathrm{C}$ ratios of COA were 0.10 and 1.69 , respectively, similar to those at other urban results such as 0.11 and 1.73 in Beijing (Huang et al., 2010), 0.11 and 1.72 in Fresno (Ge et al., 2012a), and 0.13 and 1.74 in Paris (Crippa et al., 2013).

As the UMR mass spectra of COA and HOA are fairly similar, it can be difficult to distinguish them via factor analysis using data acquired with the Quadrupole AMS or ACSM (e.g., Sun et al., 2010). Past studies indicate that the rela-
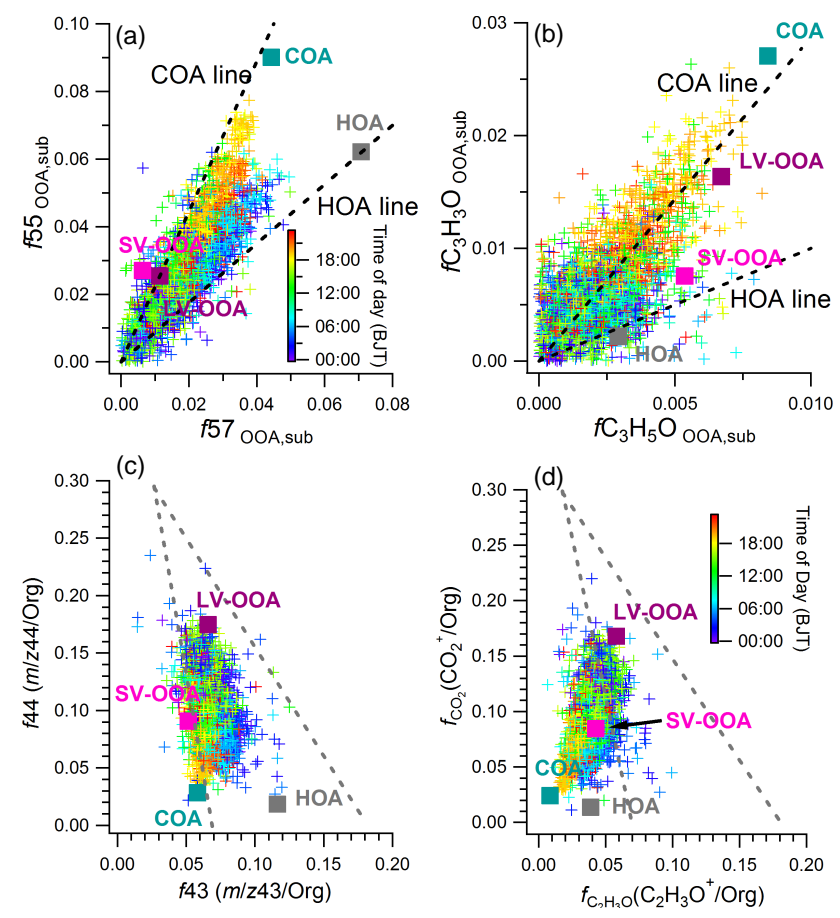

Figure 12. Scatterplots of (a) $f 55_{\mathrm{OOA}, \mathrm{sub}}$ vs. $f 57_{\mathrm{OOA}, \mathrm{sub}}$, (b) $f \mathrm{C}_{3} \mathrm{H}_{3} \mathrm{O}_{\mathrm{OOA}}$, sub vs. $f \mathrm{C}_{3} \mathrm{H}_{5} \mathrm{O}_{\mathrm{OOA}}$, sub , (c) $f 44$ vs. $f 43$, and (d) $f \mathrm{CO}_{2}^{+}$vs. $f \mathrm{C}_{2} \mathrm{H}_{3} \mathrm{O}^{+}$. The measured OA data points are colored by time of the day. The corresponding values of the four OA factors identified by PMF in this study are also shown.

tive signal intensities of organic mass fragments at $\mathrm{m} / \mathrm{z} 55$ and 57 (i.e., $f 55$ and $f 57$ ) can be used to differentiate COA from HOA (e.g., Huang et al., 2010; Sun et al., 2010; Sun et al., 2011a). Mohr et al., (2012) proposed a V-shaped plot using $f 55$ vs. $f 57$ or the mass fraction of $\mathrm{C}_{3} \mathrm{H}_{5} \mathrm{O}^{+}$(i.e., $f \mathrm{C}_{3} \mathrm{H}_{3} \mathrm{O}^{+}$vs. $f \mathrm{C}_{3} \mathrm{H}_{5} \mathrm{O}^{+}$) after subtracting the contributions from OOA factors (denoted as $\mathrm{OOA}_{\text {sub }}$ ) to distinguish the $\mathrm{COA}$ and HOA. In Fig. 12a and b, the V-shape formed by the two dashed lines defines the edges of the COA and the HOA factors from several urban AMS data sets (Mohr et al., 2012). The COA and HOA factors determined by PMF are well separated in the plot of $f 55_{\mathrm{OOA}}$, sub vs. $f 57_{\mathrm{OOA}}$, sub with COA resides at the left end side and HOA at the right end side of the $\mathrm{V}$-shape region. By coloring the data points according to time of day, we can clearly see the diurnal characteristics as most points during dinner time are situated around the COA line.

The good correlation between the temporal variations of $\mathrm{COA}$ and $\mathrm{C}_{6} \mathrm{H}_{10} \mathrm{O}^{+}$was consistent with the observations at New York (Sun et al., 2011a) and Fresno (Ge et al., 2012a). The diurnal variation (Fig. 10b) of COA was distinctly different from that of HOA, with three peaks responding to breakfast, lunch, and dinner time, respectively.

The average mass contribution of COA to the total organic mass was $24 \%$, larger than that of HOA (16\%) (Fig. 10c). 
The higher COA fraction compared to HOA was also observed at Beijing (COA: $24 \%$ vs. HOA: $18 \%$ ) (Huang et al., 2010), New York (COA: $16 \%$ vs. HOA: $14 \%$ ) (Sun et al., 2011a), Barcelona (COA: $17 \%$ vs. HOA: $16 \%$ ) (Mohr et al., 2012), and Paris (COA: $14.7 \%$ vs. HOA: $12 \%$ ) (Crippa et al., 2013), which underscores that food cooking, including seed oil frying and meat charbroiling, can be an important source of fine OA in urban environments (Abdullahi et al., 2013). The contribution of COA was insignificant at afternoon ( $\sim 10 \%$ of the total OA mass), but can account for up to $\sim 50 \%$ of the total OA mass during dinner time (Fig. 10d).

The COA size distribution peaked at $\sim 150 \mathrm{~nm}$ (Fig. 11a), which was slightly smaller than that of Fresno COA $(\sim 200 \mathrm{~nm})$ (Ge et al., 2012a). Although COA and HOA both peaked at $\sim 150 \mathrm{~nm}$, the size distribution of COA was narrower than that of HOA, suggesting a more uniform origin and/or the more spherical COA particles (oil droplet). The size distribution of $m / z 55$ seemed to over-predict the COA mass in the larger size range (Fig. S11a), due to the influence of aged OA which produces ions at $\mathrm{m} / \mathrm{z} 55$ as well. COA in this study dominated the ultrafine size range $(50-150 \mathrm{~nm}$ in $D_{\text {va }}$, Fig.11b), further suggesting that the COA in Lanzhou was fresh OA.

\subsubsection{SV-OOA and LV-OOA}

OOA has been separated via multivariate factor analysis of AMS field measurement data around the globe (Zhang et al., 2011a). A key feature of various OOA mass spectra is the presence of a prominent $\mathrm{m} / \mathrm{z} 44\left(\mathrm{CO}_{2}^{+}\right)$peak. Two subtypes of OOA, SV-OOA and LV-OOA, are frequently identified using PMF, and SV-OOA is less oxidized than LV-OOA. The mass spectra of LV-OOA and SV-OOA identified in this study both contained prominent peaks at $\mathrm{m} / \mathrm{z} 44$ (mainly $\mathrm{CO}_{2}^{+}$), 29 (mainly $\mathrm{CHO}^{+}$), but $\mathrm{SV}$-OOA had a relative higher peak at $\mathrm{m} / z, 43$ (mainly $\mathrm{C}_{2} \mathrm{H}_{3} \mathrm{O}^{+}$) (Fig. 9g and 9h). The LVOOA mass spectrum comprised $21 \%$ of $\mathrm{C}_{\mathrm{x}} \mathrm{H}_{\mathrm{y}} \mathrm{O}_{2}^{+}$ions, $42 \%$ of $\mathrm{C}_{\mathrm{x}} \mathrm{H}_{\mathrm{y}} \mathrm{O}_{1}^{+}$ions, and $30 \%$ of $\mathrm{C}_{\mathrm{x}} \mathrm{H}_{\mathrm{y}}^{+}$ions, in contrast to $9.3 \%, 27 \%$, and $58 \%$, respectively, in SV-OOA. The time series of LV-OOA showed tightest correlation with $\mathrm{C}_{\mathrm{x}} \mathrm{H}_{\mathrm{y}} \mathrm{O}_{2}^{+}$ ions followed by $\mathrm{C}_{x} \mathrm{H}_{y} \mathrm{O}^{+}$(Fig. S7d); while SV-OOA correlated best with $\mathrm{C}_{\mathrm{x}} \mathrm{H}_{\mathrm{y}} \mathrm{O}^{+}$ions followed by $\mathrm{C}_{\mathrm{x}} \mathrm{H}_{\mathrm{x}-2}^{+}$ions (Fig. S7c). As shown in Fig. S8j-o, the SV-OOA and LVOOA mass spectra of this study correlated well, respectively, with the reference UMR spectra of SV-OOA $\left(r^{2}=0.68\right)$, and LV-OOA $\left(r^{2}=0.73\right)$ reported in $\mathrm{Ng}$ et al. (2011a) and the high mass resolution spectra of SV-OOA and LV-OOA from New York City $\left(r^{2}=0.85\right.$ and 0.99 , respectively) (Sun et al., 2011a) and Barcelona ( $r^{2}=0.84$ and 0.98 , respectively) (Mohr et al., 2012). The $\mathrm{O} / \mathrm{C}$ and $\mathrm{H} / \mathrm{C}$ ratios were 0.68 and 1.34 for LV-OOA, and 0.28 and 1.34 for SV-OOA (Fig. $9 \mathrm{~g}$ and h). The $f 44$ vs. $f 43$ or $f \mathrm{CO}_{2}^{+}$vs. $f \mathrm{C}_{2} \mathrm{H}_{3} \mathrm{O}^{+}$of LVOOA and SV-OOA in triangle plot (Ng et al., 2010) were higher than those of HOA and COA and located at the middle of plot with LV-OOA at the upper position (Fig. 12c and d). Compared to the AMS observations available in China, the $\mathrm{O} / \mathrm{C}$ of LV-OOA (0.68) in Lanzhou is higher than that in Beijing (0.48) (Huang et al., 2010), Shanghai (0.65) (Huang et al., 2012), Shenzhen (0.59) (He et al., 2011), Guangzhou (0.64) (Huang et al., 2011), likely due to the strong solar radiation in Lanzhou during this study. However, it was less oxidized than the LV-OOA observed at a suburban location in Hong Kong (0.80) (Lee et al., 2013).

The chemical feature of LV-OOA and SV-OOA can further be evaluated by their correlations with secondary sulfate and nitrate. The time series of LV-OOA correlated better with sulfate than with nitrate $\left(r^{2}=0.41\right.$ vs. 0.15 , Table 1$)$, while SV-OOA correlated better with nitrate than with sulfate $\left(r^{2}=0.50\right.$ vs. 0.19 , Table 1$)$, consistent with the assumption about their volatilities. The diurnal patterns (Fig. 10b) also illustrated the different evolution processes of these two factors: LV-OOA presented an afternoon peak in accordance with strong photochemical activities for producing highly oxidized secondary organic species, while SV-OOA peaked in later morning similarly to the behavior of nitrate, indicating the roles of dynamics of residual layer and nocturnal chemistry for SV-OOA formation and transport. The high correlation between SV-OOA and the ions of $\mathrm{C}_{\mathrm{x}} \mathrm{H}_{\mathrm{x}-2}^{+}$suggested the important contribution of aromatic compounds in Lanzhou, which was likely related to coal combustion activities. Indeed, the mass spectrum of SV-OOA was similar to that of coal combustion from a chamber study (Dall'Osto et al., 2013) with the higher $\mathrm{C}_{\mathrm{x}} \mathrm{H}_{\mathrm{y}}^{+}$peaks at $m / z 69,77,91$, and 115.

On average, SOA represented a higher fraction (59\%) of the total OA mass than POA did, with SV-OOA and LV-OOA accounting for $27 \%$ and $32 \%$, respectively (Fig. 10c). The diurnal pattern of the fractional contributions of all OA components (Fig. 10d) indicated that SOA can occupy up to $80 \%$ of OA mass during afternoon, mainly because of LV-OOA. SV-OOA and LV-OOA increased during morning with the increase of LV-OOA slightly later than of SV-OOA (Fig. 10b). In addition, the mass of fraction of LV-OOA increased continually during afternoon whereas the SV-OOA mass fraction decreased, indicating photochemical processing of OA. A similar phenomenon was observed in New York City during summer (Sun et al., 2011b). These processes could also be evident from the $\mathrm{O} / \mathrm{C}$ trend in bulk $\mathrm{OA}$, which increased from morning time and had a broad afternoon hump. Two peaks of N/C appeared at late morning and afternoon, respectively, also suggesting the formation of $\mathrm{N}$-containing organic compounds during the photochemical process. SOA (=SV$\mathrm{OOA}+\mathrm{LV}-\mathrm{OOA}$ ) on average accounted for $40-50 \%$ during rush hour and dinner time, with equal contributions from SVOOA and LV-OOA (Fig. 10d). Comparison of our 2012 results and previous studies at other Chinese cities showed that the importance of OOA as an OA component in Lanzhou is close to that in Beijing ( $\sim 60 \%$ in 2006-2011 summer) (Huang et al., 2010; Sun et al., 2010; Sun et al., 2012a), but lower than that in 2010 Shanghai (76\%) (Huang et al., 

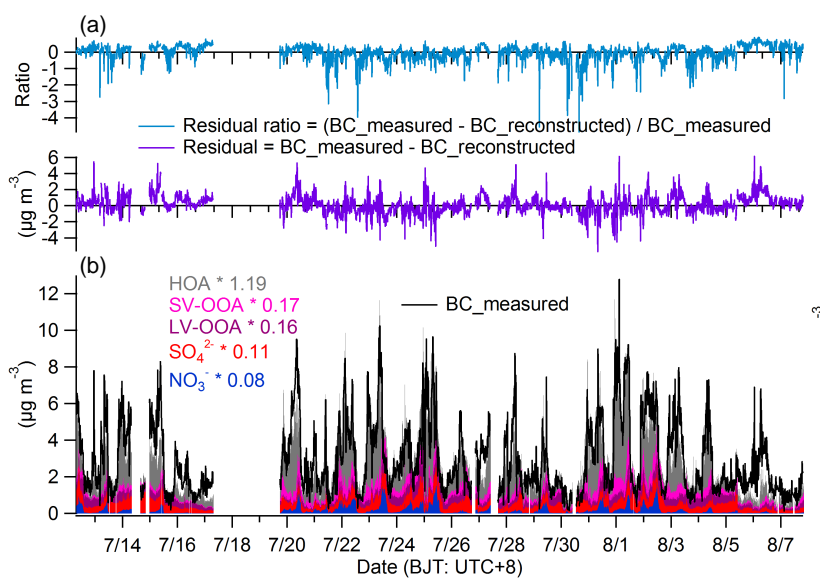
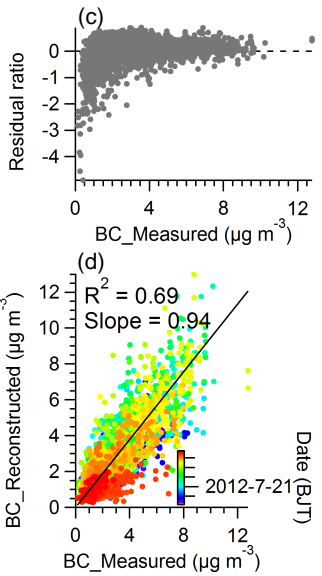

(e)

(f)

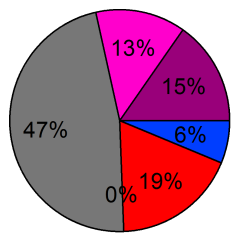

LV-OOA SV-OOA COA HOA SO ${ }_{1}^{2-} \mathrm{NO}_{2}$

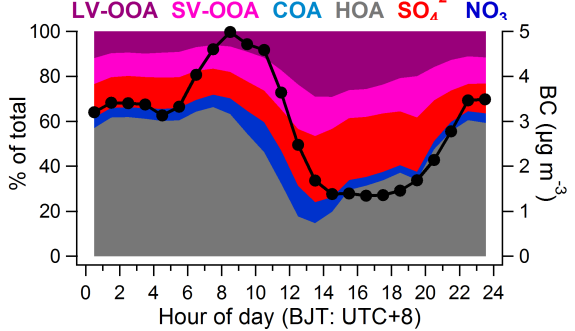

Figure 13. Diagnostics plots for BC decomposition and results. (a) Time series of the ratio of the residual to the measured BC and variations of the absolute fitting residuals; (b) time series of the measured BC and the stacked contributions of all fitted species; (c) the scatterplot between the residuals and measured BC; (d) the scatterplot and linear fit between measured and reconstructed BC; (e) the average contribution of different components to $\mathrm{BC}$; (f) diurnal cycles of the contribution of different components and the total BC mass concentrations.

2012) and Pearl River Delta during 2006 and 2011 ( 75\%) (Huang et al., 2011; Lee et al., 2013).

The average mass-based size distribution of OOA peaked between 400 and $500 \mathrm{~nm}$ in $D_{\text {va }}$, similar to that of $\mathrm{m} / \mathrm{z}$ 44 (Fig. S11c). This size distribution is also similar to the OOA size distribution observed in Fresno (Ge et al., 2012a). The size-resolved mass fraction of OA showed the dominance (over $70 \%$ ) of OOA in accumulation mode particles (Fig. 11b).

\subsection{The sources of $\mathrm{BC}$}

Ambient BC can be freshly emitted from combustion sources or transported in aged air massed together with other species. The linear decomposition algorithm of Eq. (2) determined that:

$$
\begin{array}{r}
\operatorname{ts}_{\mathrm{BC}}=1.19 \times \mathrm{ts}_{\mathrm{HOA}}+0 \times \mathrm{ts}_{\mathrm{COA}}+0.17 \times \mathrm{ts}_{\mathrm{SV}-\mathrm{OOA}} \\
+0.16 \times \mathrm{ts}_{\mathrm{LV}-\mathrm{OOA}} \\
+0.11 \times \mathrm{ts}_{\mathrm{SO}_{4}}+0.08 \times \mathrm{ts}_{\mathrm{NO}_{3}}
\end{array}
$$

Where, $\mathrm{ts}_{\mathrm{BC}}, \mathrm{ts}_{\mathrm{HOA}}$, ts $\mathrm{COA}_{\mathrm{COA}}$, ts $\mathrm{SV}-\mathrm{OOA}, \mathrm{ts}_{\mathrm{LV}-\mathrm{OOA}}, \mathrm{ts}_{\mathrm{SO}_{4}}$, and $\mathrm{ts}_{\mathrm{NO}_{3}}$ are the time series of BC, HOA, COA, SV-OOA, LVOOA, sulfate and nitrate, respectively. As shown in Fig. 13b, good agreement was observed between the measured and the reconstructed $\mathrm{BC}$ concentrations, with a linear regression slope $=0.94$ and $r^{2}=0.69$ (Fig. 13d). Note that the different local environment for BC and AMS measurements could generate a certain uncertainty for the variation of $\mathrm{BC}$ and AMS data sets.

As shown in Fig. 13e, a major species mixed with $\mathrm{BC}$ was HOA $(47 \%)$. The mass fractions of $\mathrm{BC}$ were associated with the other aerosol species were: sulfate (18\%), LV-OOA $(15 \%)$, SV-OOA $(13 \%)$, and nitrate $(6 \%)$. COA showed no correlation with BC. These result suggested that approxi- mately half of the BC-containing particles in Lanzhou originated from fossil fuel combustion (HOA), whereas another half was associated with aged aerosols. Meanwhile, these results also suggest that organics were internally mixed with BC, similar to observations reported in other studies (Shiraiwa et al., 2007; Liu et al., 2013). The relatively stronger association of BC with sulfate than with nitrate in summer was likely due to the higher volatility of ammonium nitrate than ammonium sulfate (Riemer et al., 2004). Diurnal variations of the sources of BC (Fig. 13f) revealed higher mass fraction $(\sim 60 \%)$ associated with HOA from midnight to morning rush hour; the fractions of $\mathrm{BC}$ associated with LV-OOA and sulfate showed an enhancement by $\sim 30 \%$ during afternoon; the fraction of $\mathrm{BC}$ associated with nitrate showed an enhanced contribution in late morning (up to $\sim 10 \%$ ), while that of SV-OOA was relatively stable throughout the day.

\subsection{Polycyclic aromatic hydrocarbons (PAHs)}

PAHs are known to have significant adverse health effects (Nisbet and LaGoy, 1992). Generally, PAHs are a group of environmental pollutants containing two or more fused benzene rings, and formed through high-temperature incomplete combustion and pyrolysis of fossil fuels and other organic materials. Major anthropogenic sources include coal and wood burning, gasoline and diesel oil combustions, and various industrial processes (Baek et al., 1991). The concentrations of particle-bound PAHs in this study (Fig. 14a) were estimated based on the method reported by Dzepina et al. (2007), which estimated total particulate PAH concentration by subtracting the relevant ion signals from $\mathrm{m} / z 198$ to 328 in the UMR spectrum of OA. In this study, due to the availability of the high-resolution (W-mode) data, we directly quantified the PAH-relevant ions in the range of $\mathrm{m} / \mathrm{z}$ 


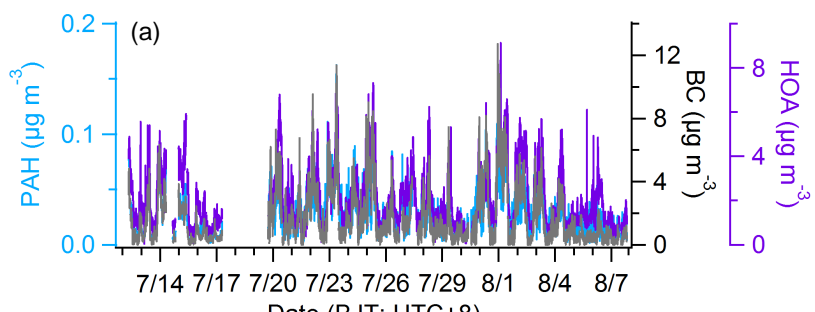

(b)
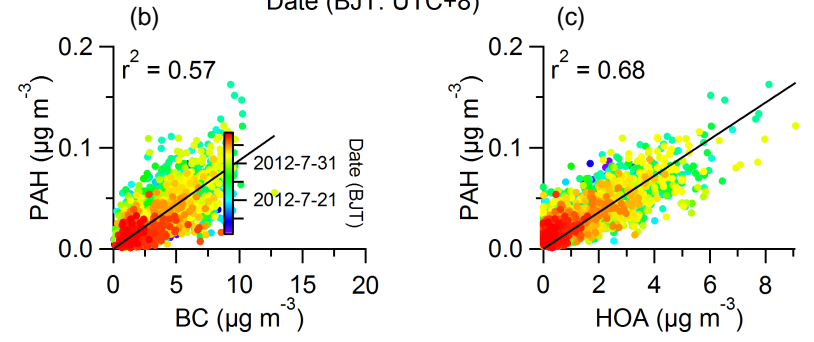

Figure 14. (a) Time series of PAHs, BC, and HOA; scatterplots of PAHs with (b) BC and (c) HOA. The data points are colored by measurement date.

202 to 328 , and applied the RIE (relative ionization efficiency) suggested by Dzepina et al. (2007).

The average PAHs concentration was determined at $26 \mathrm{ng} \mathrm{m}^{-3}$ in this study, consistent with other observations in China during summer periods (10-50 $\mathrm{ng} \mathrm{m}^{-3}$ ) (Liu et al., 2010; Gao et al., 2011; Gong et al., 2011). The time series of PAHs was correlated with BC $\left(r^{2}=0.57\right.$, Fig. $\left.14 \mathrm{~b}\right)$ and HOA $\left(r^{2}=0.68\right.$, Fig. $\left.14 \mathrm{c}\right)$, suggesting that traffic emission was the most important source of PAHs. This result was in accordance with the findings in other Chinese cities based on the chemical-tracer derived method (Guo et al., 2003; Mai et al., 2003; Liu et al., 2010). The correlation between COA and PAHs was poor $\left(r^{2}=0.15\right.$, Fig. S12), indicating that cooking was not a source of PAHs in Lanzhou.

\section{Conclusions}

In this study, the chemistry of submicron particles was investigated during summer 2012 in Lanzhou, northwest China, using a suit of real-time instruments. The average mass concentration of $\mathrm{PM}_{1}$ was $24.5( \pm 15.2) \mu \mathrm{g} \mathrm{m} \mathrm{m}^{-3}$ for the entire study with organics accounting for $47 \%$, following by sulfate $(16 \%), \mathrm{BC}(12 \%)$, ammonium (11\%), nitrate $(10 \%)$, and chloride $(4 \%)$. The average size distribution presented an overlapping accumulation mode peaking at $\sim 400 \mathrm{~nm}$ in vacuum aerodynamic diameter $\left(D_{\mathrm{va}}\right)$ for sulfate, nitrate, chloride, and ammonium, while organics showed a much broader peak ranging from $\sim 100$ to $\sim 500 \mathrm{~nm}$. The diurnal pattern of organics showed a significant peak between 07:00 and 13:00 (BJT: UTC +8) and an early evening peak between 18:00 and 22:00, which were related to local traffic emissions during rush hours, turbulent mixing, photooxidation, and cooking emissions during meal times. Sulfate presented a very broad peak between 09:00 and 16:00, indicating the photochemical production. Nitrate, on the other hand, showed a diurnal pattern peaking at 09:00-13:00, which was likely related to the dynamics of the urban boundary layer. Four OA factors were identified by PMF analysis of the high-resolution mass spectra, including HOA (16\% of total organics), COA (24\%), SV-OOA (27\%), and LV-OOA ( $32 \%$ ). The HOA factor correlated well with $\mathrm{BC}$, while the SV-OOA and LV-OOA correlated well with nitrate and sulfate, respectively. The diurnal variation of COA peaked during three meal times, while the diurnal level of SV-OOA peaked during morning time similarly to that of nitrate, suggesting the influence dynamics of the urban boundary layer; the diurnal pattern of LV-OOA peaked during afternoon, corresponding with the photochemical process. The sources of BC were estimated based on the linear decomposition method, which showed that $47 \%$ of atmospheric BC mass was associated with HOA emission, while $18 \%$ with sulfate, $15 \%$ with LV-OOA, $13 \%$ with SVOOA, and $6 \%$ with nitrate. The time series of PAHs showed very good correlations with $\mathrm{BC}$ and $\mathrm{HOA}$, suggesting that traffic emission was an important source of PAHs.

\section{The Supplement related to this article is available online at doi:10.5194/acp-14-12593-2014-supplement.}

Acknowledgements. This research was supported by grants from the Science Fund for Creative Research Groups of the National Natural Science Foundation of China (NSFC) (41121001), the Scientific Research Foundation of the Key Laboratory of Cryospheric Sciences (SKLCS-ZZ-2013-01-04) and the Fundamental Research Funds for the Central Universities (lzujbky-2011-3). Qi Zhang and Xinlei Ge were supported by the Office of Science (BER), US Department of Energy (DOE), Atmospheric System Research Program, Grant No. DE-FG02-11ER65293. Thanks to Prof. Ye Yu for providing the meteorological data.

Edited by: Chak K. Chan

\section{References}

Abdullahi, K. L., Delgado-Saborit, J. M., and Harrison, R. M.: Emissions and indoor concentrations of particulate matter and its specific chemical components from cooking: A review, Atmos. Environ., 71, 260-294, doi:10.1016/j.atmosenv.2013.01.061, 2013.

Aiken, A. C., DeCarlo, P. F., Kroll, J. H., Worsnop, D. R., Huffman, J. A., Docherty, K. S., Ulbrich, I. M., Mohr, C., Kimmel, J. R., Sueper, D., Sun, Y., Zhang, Q., Trimborn, A., Northway, M., Ziemann, P. J., Canagaratna, M. R., Onasch, T. B., Alfarra, M. R., Prevot, A. S. H., Dommen, J., Duplissy, J., Metzger, A., Baltensperger, U., and Jimenez, J. L.: O/C and OM/OC ratios 
of primary, secondary, and ambient organic aerosols with highresolution time-of-flight aerosol mass spectrometry, Environ. Sci. Technol., 42, 4478-4485, doi:10.1021/es703009q, 2008.

Allan, J. D., Alfarra, M. R., Bower, K. N., Williams, P. I., Gallagher, M. W., Jimenez, J. L., McDonald, A. G., Nemitz, E., Canagaratna, M. R., Jayne, J. T., Coe, H., and Worsnop, D. R.: Quantitative sampling using an aerodyne aerosol mass spectrometer 2. Measurements of fine particulate chemical composition in two u.K. Cities, J. Geophys. Res., 108, 4091, doi:10.1029/2002JD002359, 2003.

Allan, J. D., Delia, A. E., Coe, H., Bower, K. N., Alfarra, M. R., Jimenez, J. L., Middlebrook, A. M., Drewnick, F., Onasch, T. B., Canagaratna, M. R., Jayne, J. T., and Worsnop, D. R.: A generalised method for the extraction of chemically resolved mass spectra from aerodyne aerosol mass spectrometer data, J. Aerosol. Sci,, 35, 909-922, doi:10.1016/j.jaerosci.2004.02.007, 2004.

Allan, J. D., Williams, P. I., Morgan, W. T., Martin, C. L., Flynn, M. J., Lee, J., Nemitz, E., Phillips, G. J., Gallagher, M. W., and Coe, H.: Contributions from transport, solid fuel burning and cooking to primary organic aerosols in two UK cities, Atmos. Chem. Phys., 10, 647-668, doi:10.5194/acp-10-647-2010, 2010.

Baek, S. O., Field, R. A., Goldstone, M. E., Kirk, P. W., Lester, J. N., and Perry, R.: A review of atmospheric polycyclic aromatic hydrocarbons: Sources, fate and behavior, Water. Air. Soil. Pollut., 60, 279-300, doi:10.1007/bf00282628, 1991.

Bond, T., and Bergstrom, R.: Light absorption by carbonaceous particles: An investigative review, Aerosol. Sci. Tech., 40, 27-67, doi:10.1080/02786820500421521, 2006.

Brock, C. A., Trainer, M., Ryerson, T. B., Neuman, J. A., Parrish, D. D., Holloway, J. S., Nicks, D. K., Frost, G. J., Hübler, G., Fehsenfeld, F. C., Wilson, J. C., Reeves, J. M., Lafleur, B. G., Hilbert, H., Atlas, E. L., Donnelly, S. G., Schauffler, S. M., Stroud, V. R., and Wiedinmyer, C.: Particle growth in urban and industrial plumes in texas, J. Geophys. Res., 108, 4111, doi:10.1029/2002JD002746, 2003.

Brown, S. S. and Stutz, J.: Nighttime radical observations and chemistry, Chem. Soc. Rev., 41, 6405-6447, doi:10.1039/c2cs35181a, 2012.

Canagaratna, M. R., Jayne, J. T., Ghertner, D. A., Herndon, S., Shi, Q., Jimenez, J. L., Silva, P. J., Williams, P., Lanni, T., Drewnick, F., Demerjian, K. L., Kolb, C. E., and Worsnop, D. R.: Chase studies of particulate emissions from in-use new york city vehicles, Aerosol. Sci. Tech., 38, 555-573, doi:10.1080/02786820490465504, 2004.

Canagaratna, M. R., Jayne, J. T., Jimenez, J. L., Allan, J. D., Alfarra, M. R., Zhang, Q., Onasch, T. B., Drewnick, F., Coe, H., Middlebrook, A., Delia, A., Williams, L. R., Trimborn, A. M., Northway, M. J., DeCarlo, P. F., Kolb, C. E., Davidovits, P., and Worsnop, D. R.: Chemical and microphysical characterization of ambient aerosols with the aerodyne aerosol mass spectrometer, Mass. Spectrom. Rev., 26, 185-222, doi:10.1002/mas.20115, 2007.

Chan, C. K., and Yao, X.: Air pollution in mega cities in china, Atmos. Environ., 42, 1-42, doi:10.1016/j.atmosenv.2007.09.003, 2008.

Chu, P. C., Chen, Y., Lu, S., Li, Z., and Lu, Y.: Particulate air pollution in lanzhou china, Environ. Int., 34, 698-713, doi:10.1016/j.envint.2007.12.013, 2008.
Collier, S., and Zhang, Q.: Gas-phase co2 subtraction for improved measurements of the organic aerosol mass concentration and oxidation degree by an aerosol mass spectrometer, Environ. Sci. Technol., 47, 14324-14331, doi:10.1021/es404024h, 2013.

Crippa, M., El Haddad, I., Slowik, J. G., DeCarlo, P. F., Mohr, C., Heringa, M. F., Chirico, R., Marchand, N., Sciare, J., Baltensperger, U., and Prevot, A. S. H.: Identification of marine and continental aerosol sources in paris using high resolution aerosol mass spectrometry, J. Geophys. Res., 118, 1950-1963, doi:10.1002/jgrd.50151, 2013.

Dall'Osto, M., Ovadnevaite, J., Ceburnis, D., Martin, D., Healy, R. M., O'Connor, I. P., Kourtchev, I., Sodeau, J. R., Wenger, J. C., and O'Dowd, C.: Characterization of urban aerosol in cork city (ireland) using aerosol mass spectrometry, Atmos. Chem. Phys., 13, 4997-5015, doi:10.5194/acp-13-4997-2013, 2013.

DeCarlo, P. F., Kimmel, J. R., Trimborn, A., Northway, M. J., Jayne, J. T., Aiken, A. C., Gonin, M., Fuhrer, K., Horvath, T., Docherty, K. S., Worsnop, D. R., and Jimenez, J. L.: Field-deployable, high-resolution, time-of-flight aerosol mass spectrometer, Anal. Chem., 78, 8281-8289, doi:10.1021/ac061249n, 2006.

Dzepina, K., Arey, J., Marr, L. C., Worsnop, D. R., Salcedo, D., Zhang, Q., Onasch, T. B., Molina, L. T., Molina, M. J., and Jimenez, J. L.: Detection of particle-phase polycyclic aromatic hydrocarbons in mexico city using an aerosol mass spectrometer, Int. J. Mass. Spectrom., 263, 152-170, doi:10.1016/j.ijms.2007.01.010, 2007.

Gao, B., Yu, J.-Z., Li, S.-X., Ding, X., He, Q.-F., and Wang, X.M.: Roadside and rooftop measurements of polycyclic aromatic hydrocarbons in pm2.5 in urban guangzhou: Evaluation of vehicular and regional combustion source contributions, Atmos. Environ., 45, 7184-7191, doi:10.1016/j.atmosenv.2011.09.005, 2011.

Ge, X., Setyan, A., Sun, Y., and Zhang, Q.: Primary and secondary organic aerosols in fresno, california during wintertime: Results from high resolution aerosol mass spectrometry, J. Geophys. Res., 117, D19301, doi:10.1029/2012jd018026, 2012a.

Ge, X., Zhang, Q., Sun, Y., Ruehl, C. R., and Setyan, A.: Effect of aqueous-phase processing on aerosol chemistry and size distributions in fresno, california, during wintertime, Environ. Chem., 9, 221-235, doi:10.1071/EN11168, 2012b.

Gong, P., Wang, X., and Yao, T.: Ambient distribution of particulate- and gas-phase n-alkanes and polycyclic aromatic hydrocarbons in the tibetan plateau, Environ. Earth Sci., 64, 1703-1711, doi:10.1007/s12665-011-0974-3, 2011.

Guo, H., Lee, S. C., Ho, K. F., Wang, X. M., and Zou, S. C.: Particle-associated polycyclic aromatic hydrocarbons in urban air of hong kong, Atmos. Environ., 37, 5307-5317, doi:10.1016/j.atmosenv.2003.09.011, 2003.

He, L.-Y., Huang, X.-F., Xue, L., Hu, M., Lin, Y., Zheng, J., Zhang, R., and Zhang, Y.-H.: Submicron aerosol analysis and organic source apportionment in an urban atmosphere in pearl river delta of china using high-resolution aerosol mass spectrometry, J. Geophys. Res., 116, doi:10.1029/2010jd014566, 2011.

He, L. Y., Lin, Y., Huang, X. F., Guo, S., Xue, L., Su, Q., Hu, M., Luan, S. J., and Zhang, Y. H.: Characterization of high-resolution aerosol mass spectra of primary organic aerosol emissions from chinese cooking and biomass burning, Atmos. Chem. Phys., 10, 11535-11543, doi:10.5194/acp-10-11535-2010, 2010.

Hu, W. W., Hu, M., Yuan, B., Jimenez, J. L., Tang, Q., Peng, J. F., Hu, W., Shao, M., Wang, M., Zeng, L. M., Wu, Y. S., Gong, Z. 
H., Huang, X. F., and He, L. Y.: Insights on organic aerosol aging and the influence of coal combustion at a regional receptor site of central eastern china, Atmos. Chem. Phys., 13, 10095-10112, doi:10.5194/acp-13-10095-2013, 2013.

$\mathrm{Hu}, \mathrm{Y}$. and Zhang, Q.: Atmosphere pollution mechanism along with prevention and cure countermeasure of the lanzhou hollow basin, China Environ. Sci., 19, 119-122, 1999.

Huang, X.-F., Xue, L., Tian, X.-D., Shao, W.-W., Sun, T.-L., Gong, Z.-H., Ju, W.-W., Jiang, B., Hu, M., and He, L.Y.: Highly time-resolved carbonaceous aerosol characterization in yangtze river delta of china: Composition, mixing state and secondary formation, Atmos. Environ., 64, 200-207, doi:10.1016/j.atmosenv.2012.09.059, 2013.

Huang, X. F., He, L. Y., Hu, M., Canagaratna, M. R., Sun, Y., Zhang, Q., Zhu, T., Xue, L., Zeng, L. W., Liu, X. G., Zhang, Y. H., Jayne, J. T., Ng, N. L., and Worsnop, D. R.: Highly time-resolved chemical characterization of atmospheric submicron particles during 2008 beijing olympic games using an aerodyne high-resolution aerosol mass spectrometer, Atmos. Chem. Phys., 10, 8933-8945, doi:10.5194/acp-10-8933-2010, 2010.

Huang, X. F., He, L. Y., Hu, M., Canagaratna, M. R., Kroll, J. H., Ng, N. L., Zhang, Y. H., Lin, Y., Xue, L., Sun, T. L., Liu, X. G., Shao, M., Jayne, J. T., and Worsnop, D. R.: Characterization of submicron aerosols at a rural site in pearl river delta of china using an aerodyne high-resolution aerosol mass spectrometer, Atmos. Chem. Phys., 11, 1865-1877, doi:10.5194/acp-111865-2011, 2011.

Huang, X. F., He, L. Y., Xue, L., Sun, T. L., Zeng, L. W., Gong, Z. H., Hu, M., and Zhu, T.: Highly time-resolved chemical characterization of atmospheric fine particles during 2010 shanghai world expo, Atmos. Chem. Phys., 12, 4897-4907, doi:10.5194/acp-12-4897-2012, 2012.

Jayne, J. T., Leard, D. C., Zhang, X., Davidovits, P., Smith, K. A., Kolb, C. E., and Worsnop, D. R.: Development of an aerosol mass spectrometer for size and composition analysis of submicron particles, Aerosol. Sci. Tech., 33, 49-70, doi:10.1080/027868200410840, 2000.

Jimenez, J. L., Canagaratna, M. R., Donahue, N. M., Prevot, A. S. H., Zhang, Q., Kroll, J. H., DeCarlo, P. F., Allan, J. D., Coe, H., Ng, N. L., Aiken, A. C., Docherty, K. S., Ulbrich, I. M., Grieshop, A. P., Robinson, A. L., Duplissy, J., Smith, J. D., Wilson, K. R., Lanz, V. A., Hueglin, C., Sun, Y. L., Tian, J., Laaksonen, A., Raatikainen, T., Rautiainen, J., Vaattovaara, P., Ehn, M., Kulmala, M., Tomlinson, J. M., Collins, D. R., Cubison, M. J., E., Dunlea, J., Huffman, J. A., Onasch, T. B., Alfarra, M. R., Williams, P. I., Bower, K., Kondo, Y., Schneider, J., Drewnick, F., Borrmann, S., Weimer, S., Demerjian, K., Salcedo, D., Cottrell, L., Griffin, R., Takami, A., Miyoshi, T., Hatakeyama, S., Shimono, A., Sun, J. Y., Zhang, Y. M., Dzepina, K., Kimmel, J. R., Sueper, D., Jayne, J. T., Herndon, S. C., Trimborn, A. M., Williams, L. R., Wood, E. C., Middlebrook, A. M., Kolb, C. E., Baltensperger, U., and Worsnop, D. R.: Evolution of organic aerosols in the atmosphere, Science, 326, 1525-1529, doi:10.1126/science.1180353, 2009.

Lee, A. K. Y., Willis, M. D., Healy, R. M., Onasch, T. B., and Abbatt, J. P. D.: Single particle characterization using the soot particle aerosol mass spectrometer (SP-AMS), Atmos. Chem. Phys. Discuss., 14, 15323-15361, doi:10.5194/acpd-14-153232014, 2014.
Lee, B. P., Li, Y. J., Yu, J. Z., Louie, P. K. K., and Chan, C. K.: Physical and chemical characterization of ambient aerosol by hrtof-ams at a suburban site in hong kong during springtime 2011, J. Geophys. Res., doi:10.1002/jgrd.50658, 2013.

Liu, D., Allan, J., Whitehead, J., Young, D., Flynn, M., Coe, H., McFiggans, G., Fleming, Z. L., and Bandy, B.: Ambient black carbon particle hygroscopic properties controlled by mixing state and composition, Atmos. Chem. Phys., 13, 2015-2029, doi:10.5194/acp-13-2015-2013, 2013.

Liu, G., Tong, Y., Luong, J. H. T., Zhang, H., and Sun, H.: A source study of atmospheric polycyclic aromatic hydrocarbons in shenzhen, south china, Environ. Monit. Assess., 163, 599-606, doi:10.1007/s10661-009-0862-4, 2010.

Liu, Q., Sun, Y., Hu, B., Liu, Z., Akio, S., and Wang, Y.: In situ measurement of pm1 organic aerosol in beijing winter using a high-resolution aerosol mass spectrometer, Chinese Sci. Bull., 57, 819-826, doi:10.1007/s11434-011-4886-0, 2012.

Lu, Z., Zhang, Q., and Streets, D. G.: Sulfur dioxide and primary carbonaceous aerosol emissions in china and india, 1996-2010, Atmos. Chem. Phys., 11, 9839-9864, doi:10.5194/acp-11-98392011, 2011.

Lurmann, F. W., Brown, S. G., McCarthy, M. C., and Roberts, P. T.: Processes influencing secondary aerosol formation in the san joaquin valley during winter, J. Air Waste Manage., 56, 1679-1693, doi:10.1080/10473289.2006.10464573, 2006.

Mai, B. X., Qi, S. H., Zeng, E. Y., Yang, Q. S., Zhang, G., Fu, J. M., Sheng, G. Y., Peng, P. N., and Wang, Z. S.: Distribution of polycyclic aromatic hydrocarbons in the coastal region off macao, china: Assessment of input sources and transport pathways using compositional analysis, Environ. Sci. Technol., 37, 4855-4863, doi:10.1021/es034514k, 2003.

Mohr, C., Huffman, J. A., Cubison, M. J., Aiken, A. C., Docherty, K. S., Kimmel, J. R., Ulbrich, I. M., Hannigan, M., and Jimenez, J. L.: Characterization of primary organic aerosol emissions from meat cooking, trash burning, and motor vehicles with highresolution aerosol mass spectrometry and comparison with ambient and chamber observations, Environ. Sci. Technol., 43, 2443-2449, doi:10.1021/es8011518, 2009.

Mohr, C., DeCarlo, P. F., Heringa, M. F., Chirico, R., Slowik, J. G., Richter, R., Reche, C., Alastuey, A., Querol, X., Seco, R., Penuelas, J., Jimenez, J. L., Crippa, M., Zimmermann, R., Baltensperger, U., and Prevot, A. S. H.: Identification and quantification of organic aerosol from cooking and other sources in barcelona using aerosol mass spectrometer data, Atmos. Chem. Phys., 12, 1649-1665, doi:10.5194/acp-12-1649-2012, 2012.

Nemitz, E., Jimenez, J. L., Huffman, J. A., Ulbrich, I. M., Canagaratna, M. R., Worsnop, D. R., and Guenther, A. B.: An eddycovariance system for the measurement of surface/atmosphere exchange fluxes of submicron aerosol chemical species - first application above an urban area, Aerosol Sci. Tech., 42, 636-657, doi:10.1080/02786820802227352, 2008.

Ng, N. L., Canagaratna, M. R., Zhang, Q., Jimenez, J. L., Tian, J., Ulbrich, I. M., Kroll, J. H., Docherty, K. S., Chhabra, P. S., Bahreini, R., Murphy, S. M., Seinfeld, J. H., Hildebrandt, L., Donahue, N. M., DeCarlo, P. F., Lanz, V. A., Prévôt, A. S. H., Dinar, E., Rudich, Y., and Worsnop, D. R.: Organic aerosol components observed in northern hemispheric datasets from aerosol mass spectrometry, Atmos. Chem. Phys., 10, 4625-4641, doi:10.5194/acp-10-4625-2010, 2010. 
Ng, N. L., Canagaratna, M. R., Jimenez, J. L., Zhang, Q., Ulbrich, I. M., and Worsnop, D. R.: Real-time methods for estimating organic component mass concentrations from aerosol mass spectrometer data, Environ. Sci. Technol., 45, 910-916, doi:10.1021/es102951k, 2011a.

Ng, N. L., Herndon, S. C., Trimborn, A., Canagaratna, M. R., Croteau, P. L., Onasch, T. B., Sueper, D., Worsnop, D. R., Zhang, Q., Sun, Y. L., and Jayne, J. T.: An aerosol chemical speciation monitor (acsm) for routine monitoring of the composition and mass concentrations of ambient aerosol, Aerosol Sci. Tech., 45, 780-794, doi:10.1080/02786826.2011.560211, 2011 b.

Nilsson, E. D., Rannik, Ü., Kulmala, M., Buzorius, G., and O'Dowd, C. D.: Effects of continental boundary layer evolution, convection, turbulence and entrainment, on aerosol formation, Tellus B, 53, 441-461, doi:10.1034/j.1600-0889.2001.530409.x, 2001.

Nisbet, I. C. T., and LaGoy, P. K.: Toxic equivalency factors (tefs) for polycyclic aromatic hydrocarbons (pahs), Regul. Toxicol. Pharm., 16, 290-300, doi:10.1016/0273-2300(92)90009-X, 1992.

Paatero, P., and Tapper, U.: Positive matrix factorization: A non-negative factor model with optimal utilization of error estimates of data values, Environmetrics, 5, 111-126, doi:10.1002/env.3170050203, 1994.

Pathak, R. K., Wang, T., Ho, K. F., and Lee, S. C.: Characteristics of summertime pm2.5 organic and elemental carbon in four major chinese cities: Implications of high acidity for watersoluble organic carbon (wsoc), Atmos. Environ., 45, 318-325, doi:10.1016/j.atmosenv.2010.10.021, 2011a.

Pathak, R. K., Wang, T., and Wu, W. S.: Nighttime enhancement of pm2.5 nitrate in ammonia-poor atmospheric conditions in beijing and shanghai: Plausible contributions of heterogeneous hydrolysis of n2o5 and hno3 partitioning, Atmos. Environ., 45, 1183-1191, doi:10.1016/j.atmosenv.2010.09.003, $2011 \mathrm{~b}$.

Qu, W. J., Arimoto, R., Zhang, X. Y., Zhao, C. H., Wang, Y. Q., Sheng, L. F., and Fu, G.: Spatial distribution and interannual variation of surface pm10 concentrations over eighty-six chinese cities, Atmos. Chem. Phys., 10, 5641-5662, doi:10.5194/acp-105641-2010, 2010.

Riemer, N., Vogel, H., and Vogel, B.: Soot aging time scales in polluted regions during day and night, Atmos. Chem. Phys., 4, 1885-1893, doi:10.5194/acp-4-1885-2004, 2004.

Salcedo, D., Onasch, T. B., Dzepina, K., Canagaratna, M. R., Zhang, Q., Huffman, J. A., DeCarlo, P. F., Jayne, J. T., Mortimer, P., Worsnop, D. R., Kolb, C. E., Johnson, K. S., Zuberi, B., Marr, L. C., Volkamer, R., Molina, L. T., Molina, M. J., Cardenas, B., Bernabé, R. M., Márquez, C., Gaffney, J. S., Marley, N. A., Laskin, A., Shutthanandan, V., Xie, Y., Brune, W., Lesher, R., Shirley, T., and Jimenez, J. L.: Characterization of ambient aerosols in mexico city during the mcma-2003 campaign with aerosol mass spectrometry: Results from the cenica supersite, Atmos. Chem. Phys., 6, 925-946, doi:10.5194/acp-6-925-2006, 2006.

Sanchez-Lorenzo, A., Laux, P., Franssen, H. J. H., Calbo, J., Vogl, S., Georgoulias, A. K., and Quaas, J.: Assessing large-scale weekly cycles in meteorological variables: A review, Atmos. Chem. Phys., 12, 5755-5771, doi:10.5194/acp-12-5755-2012, 2012.
Setyan, A., Zhang, Q., Merkel, M., Knighton, W. B., Sun, Y., Song, C., Shilling, J. E., Onasch, T. B., Herndon, S. C., Worsnop, D. R., Fast, J. D., Zaveri, R. A., Berg, L. K., Wiedensohler, A., Flowers, B. A., Dubey, M. K., and Subramanian, R.: Characterization of submicron particles influenced by mixed biogenic and anthropogenic emissions using high-resolution aerosol mass spectrometry: Results from cares, Atmos. Chem. Phys., 12, 8131-8156, doi:10.5194/acp-12-8131-2012, 2012.

Shiraiwa, M., Kondo, Y., Moteki, N., Takegawa, N., Miyazaki, Y., and Blake, D. R.: Evolution of mixing state of black carbon in polluted air from tokyo, Geophys. Res. Let., 34, doi:10.1029/2007g1029819, 2007.

Sun, J. Y., Zhang, Q., Canagaratna, M. R., Zhang, Y. M., Ng, N. L., Sun, Y. L., Jayne, J. T., Zhang, X. C., Zhang, X. Y., and Worsnop, D. R.: Highly time- and size-resolved characterization of submicron aerosol particles in beijing using an aerodyne aerosol mass spectrometer, Atmos. Environ., 44, 131-140, doi:10.1016/j.atmosenv.2009.03.020, 2010.

Sun, Y., Wang, Z., Dong, H., Yang, T., Li, J., Pan, X., Chen, P., and Jayne, J. T.: Characterization of summer organic and inorganic aerosols in beijing, china with an aerosol chemical speciation monitor, Atmos. Environ., 51, 250-259, doi:10.1016/j.atmosenv.2012.01.013, 2012a.

Sun, Y. L., Zhang, Q., Schwab, J. J., Demerjian, K. L., Chen, W. N., Bae, M. S., Hung, H. M., Hogrefe, O., Frank, B., Rattigan, O. V., and Lin, Y. C.: Characterization of the sources and processes of organic and inorganic aerosols in new york city with a high-resolution time-of-flight aerosol mass apectrometer, Atmos. Chem. Phys., 11, 1581-1602, doi:10.5194/acp-11-15812011, 2011a.

Sun, Y. L., Zhang, Q., Schwab, J. J., Chen, W. N., Bae, M. S., Lin, Y. C., Hung, H. M., and Demerjian, K. L.: A case study of aerosol processing and evolution in summer in new york city, Atmos. Chem. Phys., 11, 12737-12750, doi:10.5194/acp-11-12737-201, $2011 b$.

Sun, Y. L., Zhang, Q., Schwab, J. J., Yang, T., Ng, N. L., and Demerjian, K. L.: Factor analysis of combined organic and inorganic aerosol mass spectra from high resolution aerosol mass spectrometer measurements, Atmos. Chem. Phys., 12, 8537-8551, doi:10.5194/acp-12-8537-2012, 2012 b.

Sun, Y. L., Wang, Z. F., Fu, P. Q., Yang, T., Jiang, Q., Dong, H. B., Li, J., and Jia, J. J.: Aerosol composition, sources and processes during wintertime in beijing, china, Atmos. Chem. Phys., 13, 4577-4592, doi:10.5194/acp-13-4577-2013, 2013.

Takegawa, N., Miyakawa, T., Kawamura, K., and Kondo, Y.: Contribution of selected dicarboxylic and $\omega$-oxocarboxylic acids in ambient aerosol to the $\mathrm{m} / z$, 44 signal of an aerodyne aerosol mass spectrometer, Aerosol. Sci. Tech., 41, 418-437, doi:10.1080/02786820701203215, 2007.

Takegawa, N., Miyakawa, T., Kuwata, M., Kondo, Y., Zhao, Y., Han, S., Kita, K., Miyazaki, Y., Deng, Z., Xiao, R., Hu, M., van Pinxteren, D., Herrmann, H., Hofzumahaus, A., Holland, F., Wahner, A., Blake, D. R., Sugimoto, N., and Zhu, T.: Variability of submicron aerosol observed at a rural site in beijing in the summer of 2006, J. Geophys. Res., 114, D00G05, doi:10.1029/2008jd010857, 2009.

Ulbrich, I. M., Canagaratna, M. R., Zhang, Q., Worsnop, D. R., and Jimenez, J. L.: Interpretation of organic components from positive matrix factorization of aerosol mass spectrometric data, At- 
mos. Chem. Phys., 9, 2891-2918, doi:10.5194/acp-9-2891-2009, 2009.

Ulbrich, I. M., Canagaratna, M. R., Cubison, M. J., Zhang, Q., Ng, N. L., Aiken, A. C., and Jimenez, J. L.: Three-dimensional factorization of size-resolved organic aerosol mass spectra from mexico city, Atmos. Meas. Tech., 5, 195-224, doi:10.5194/amt5-195-2012, 2012.

Wang, L., Zhang, P., Tan, S., Zhao, X., Cheng, D., Wei, W., Su, J., and Pan, X.: Assessment of urban air quality in china using air pollution indices (apis), J. Air Waste Manage., 63, 170-178, doi:10.1080/10962247.2012.739583, 2012.

Wang, S., Wang, J., Zhou, Z., and Shang, K.: Regional characteristics of three kinds of dust storm events in china, Atmos. Environ., 39, 509-520, doi:10.1016/j.atmosenv.2004.09.033, 2005.

Watson, J. G., and Chow, J. C.: A wintertime pm2.5 episode at the fresno, ca, supersite, Atmos. Environ., 36, 465-475, doi:10.1016/S1352-2310(01)00309-0, 2002.

Xia, D. S., Chen, F. H., Bloemendal, J., Liu, X. M., Yu, Y., and Yang, L. P.: Magnetic properties of urban dustfall in lanzhou, china, and its environmental implications, Atmos. Environ., 42, 2198-2207, doi:10.1016/j.atmosenv.2007.11.040, 2008.

Xiao, R., Takegawa, N., Zheng, M., Kondo, Y., Miyazaki, Y., Miyakawa, T., Hu, M., Shao, M., Zeng, L., Gong, Y., Lu, K., Deng, Z., Zhao, Y., and Zhang, Y. H.: Characterization and source apportionment of submicron aerosol with aerosol mass spectrometer during the pride-prd 2006 campaign, Atmos. Chem. Phys., 11, 6911-6929, doi:10.5194/acp-11-6911-2011, 2011.

Yang, F., Tan, J., Zhao, Q., Du, Z., He, K., Ma, Y., Duan, F., and Chen, G.: Characteristics of pm2.5 speciation in representative megacities and across china, Atmos. Chem. Phys., 11, 5207-5219, doi:10.5194/acp-11-5207-2011, 2011.

Yu, B., Huang, C., Liu, Z., Wang, H., and Wang, L.: A chaotic analysis on air pollution index change over past 10 years in lanzhou, northwest china, Stoch. Env. Res. Risk A, 25, 643-653, doi:10.1007/s00477-011-0471-y, 2011.

Zaveri, R. A., Voss, P. B., Berkowitz, C. M., Fortner, E., Zheng, J., Zhang, R. Y., Valente, R. J., Tanner, R. L., Holcomb, D., Hartley, T. P., and Baran, L.: Overnight atmospheric transport and chemical processing of photochemically aged houston urban and petrochemical industrial plume, J. Geophys. Res., 115, doi:10.1029/2009jd013495, 2010.

Zhang, Z. and Friedlander, S. K.: A comparative study of chemical databases for fine particle chinese aerosols, Environ. Sci. Technol., 34, 4687-4694, doi:10.1021/es001147t, 2000.

Zhang, J. M., Wang, T., Ding, A. J., Zhou, X. H., Xue, L. K., Poon, C. N., Wu, W. S., Gao, J., Zuo, H. C., Chen, J. M., Zhang, X. C., and Fan, S. J.: Continuous measurement of peroxyacetyl nitrate (pan) in suburban and remote areas of western china, Atmos. Environ., 43, 228-237, doi:10.1016/j.atmosenv.2008.09.070, 2009.
Zhang, L., Cao, X., Bao, J., Zhou, B., Huang, J., Shi, J., and Bi, J.: A case study of dust aerosol radiative properties over lanzhou, china, Atmos. Chem. Phys., 10, 4283-4293, doi:10.5194/acp-104283-2010, 2010.

Zhang, Q., Alfarra, M. R., Worsnop, D. R., Allan, J. D., Coe, H., Canagaratna, M. R., and Jimenez, J. L.: Deconvolution and quantification of hydrocarbon-like and oxygenated organic aerosols based on aerosol mass spectrometry, Environ. Sci. Technol., 39, 4938-4952, doi:10.1021/es0485681, 2005a.

Zhang, Q., Canagaratna, M. R., Jayne, J. T., Worsnop, D. R., and Jimenez, J. L.: Time- and size-resolved chemical composition of submicron particles in pittsburgh: Implications for aerosol sources and processes, J. Geophys. Res., 110, D07s09, doi:10.1029/2004jd004649, 2005b.

Zhang, Q., Worsnop, D. R., Canagaratna, M. R., and Jimenez, J. L.: Hydrocarbon-like and oxygenated organic aerosols in Pittsburgh: insights into sources and processes of organic aerosols, Atmos. Chem. Phys., 5, 3289-3311, doi:10.5194/acp-5-3289-2005, 2005c.

Zhang, Q., Jimenez, J. L., Canagaratna, M. R., Allan, J. D., Coe, H., Ulbrich, I., Alfarra, M. R., Takami, A., Middlebrook, A. M., Sun, Y. L., Dzepina, K., Dunlea, E., Docherty, K., DeCarlo, P. F., Salcedo, D., Onasch, T., Jayne, J. T., Miyoshi, T., Shimono, A., Hatakeyama, S., Takegawa, N., Kondo, Y., Schneider, J., Drewnick, F., Borrmann, S., Weimer, S., Demerjian, K., Williams, P., Bower, K., Bahreini, R., Cottrell, L., Griffin, R. J., Rautiainen, J., Sun, J. Y., Zhang, Y. M., and Worsnop, D. R.: Ubiquity and dominance of oxygenated species in organic aerosols in anthropogenically-influenced northern hemisphere midlatitudes, Geophys. Res. Lett., 34, L13801, doi:10.1029/2007g1029979, 2007a.

Zhang, Q., Jimenez, J. L., Worsnop, D. R., and Canagaratna, M.: A case study of urban particle acidity and its influence on secondary organic aerosol, Environ. Sci. Technol., 41, 3213-3219, doi:10.1021/es061812j, 2007b.

Zhang, Q., Jimenez, J. L., Canagaratna, M. R., Ulbrich, I. M., Ng, N. L., Worsnop, D. R., and Sun, Y.: Understanding atmospheric organic aerosols via factor analysis of aerosol mass spectrometry: A review, Anal. Bioanal. Chem., 401, 3045-3067, doi:10.1007/s00216-011-5355-y, 2011a.

Zhang, Y. M., Zhang, X. Y., Sun, J. Y., Lin, W. L., Gong, S. L., Shen, X. J., and Yang, S.: Characterization of new particle and secondary aerosol formation during summertime in beijing, china, Tellus B, 63, 382-394, doi:10.1111/j.1600-0889.2011.00533.x, 2011b.

Zhou, Z.: Strengthen automobile exhaust control to improvements lanzhou air pollution, Gansu Environ. Res. Monit., 10, 45-48, 1997. 